\title{
Sustainable development and enhancement of cracking processes using metallic composites
}

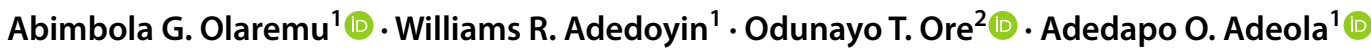

Received: 18 November 2020 / Accepted: 2 January 2021 / Published online: 23 January 2021

(c) The Author(s) 2021

\begin{abstract}
Metallic composites represent a vital class of materials that has gained increased attention in crude oil processing as well as the production of biofuel from other sources in recent times. Several catalytic materials have been reported in the literature for catalytic cracking, particularly, of crude oil. This review seeks to provide a comprehensive overview of existing and emerging methods/technologies such as metal-organic frameworks (MOFs), metal-matrix composites (MMCs), and catalytic support materials, to bridge information gaps toward sustainable advancement in catalysis for petrochemical processes. There is an increase in industrial and environmental concern emanating from the sulphur levels of oils, hence the need to develop more efficient catalysts in the hydrotreatment (HDS and HDN) processes, and combating the challenge of catalyst poisoning and deactivation; in a bid to improving the overall quality of oils and sustainable use of catalyst. Structural improvement, high thermal stability, enhanced cracking potential, and environmental sustainability represent the various benefits accrued to the use of metallic composites as opposed to conventional catalysts employed in catalytic cracking processes.
\end{abstract}

Keywords Catalyst $\cdot$ Cracking $\cdot$ Ecological restriction $\cdot$ Hydrotreatment $\cdot$ Metallic composites $\cdot$ Oil

\section{Introduction}

In a bid to refining light and heavy crude in the petroleum industry, catalytic cracking processes have evolved over the years [1-3]. The refining of heavy and extra-heavy crude particularly requires highly sophisticated processes. Cracking of petroleum generally refers to the breakdown of highly complex organic molecules such as kerogen into light hydrocarbon molecules under high temperature and pressure [4, 5]. Cracking processes could be thermal or catalytic. The former involves the decomposition of highly polymeric molecules into smaller ones under high temperature, while the latter incorporates the use of a catalyst to facilitate high

Abimbola G. Olaremu

abimbolaremu@yahoo.com; abimbola.olaremu@ aaua.edu.ng

Odunayo T. Ore

oreodunayo@yahoo.com

$\triangle$ Adedapo O. Adeola

adedapo.adeola@aaua.edu.ng

1 Department of Chemical Sciences, Adekunle Ajasin University, Akungba-Akoko, Ondo State, Nigeria

2 Department of Chemistry, Obafemi Awolowo University, Ife, Osun State, Nigeria thermal efficiency at a shorter time under low temperature and pressure [6]. Other advantages of catalytic cracking over thermal cracking include high product selectivity, high yields of gasoline, high octane number, and high aromatic yield, among others [7].

Catalyst is an essential entity in conversion and upgrading processes as it facilitates the production of valuable products without being consumed in the process. The activation energy required to reach the conversion state is lowered by the catalyst via the provision of an alternative reaction pathway [8]. The choice of catalysts used in catalytic cracking is dependent on the regenerative potential, unique microporous structure, economic cost, and thermal stability [9]. The modern-day petroleum industry commonly uses zeolite as a catalyst during catalytic cracking. Alongside every other single catalyst used in the petroleum industry, it is difficult or almost impossible for a catalyst to perform every desired reaction during cracking. Consequent upon this limitation, the impregnation of existing materials used as catalysts with other materials to form composite materials for added functionality or the synthesis of relatively new materials is an evolving technology in the petroleum industry [10-13].

At present, composites being a relatively new terminology do not have a widely accepted definition. Composites are 
obtained through the accumulation of two or more distinct materials. The fundamental constituents of composites have different distinguishing attributes and features, while the compound offers a new material [14]. Composites are made up of two or more physically and/or chemically noticeably different materials [15]. Composite materials are understood to possess their own unmatched, entirely new, and distinct properties relative to constituent components [14]. Metallic composites are useful in many areas of human endeavours, and have found application in both household materials and industrial appliances for quite some time [16-19].

The notion of mixing two dissimilar materials has received large attention in the present-day applied sciences. These combinations make possible the attainment of unique attributes [20]. The composite industry has begun to acknowledge the commercial application of composites which promise to offer enormous business opportunities in the aerospace and automotive sectors [21]. The need for structural improvement, tribological, thermal, and chemical or some other material properties is the aim of compounding this material [14]. Several components constituted the various catalysts used in cracking processes in the refining industry. An acid zeolite is crucial in achieving high activity and selectivity to light olefins; therefore, huge research efforts have been dedicated to knowing its working mechanism, since it was introduced, which is needed to enable rational improvements [22]. In particular, composite materials are composed of a matrix, constituent with the largest quantity share with other components and reinforce materials that are used to obtain projected properties. The constituents of composite materials do not mix or completely homogeneous, thereby giving rise to the presence of two or more phases within the composite material [14]. The mitigation of greenhouse gases, direct conversion of methane to methanol, and linear paraffin isomerization are specific reactions in oil refining strongly associated with the use of composite catalysts [9, 23, 24].

Many exciting research studies and reviews have focused on the synthesis, use, and catalytic activity of conventional catalysts [25-30]. Comprehensive reviews on the use of metallic composites in catalytic cracking processes are of great significance, particularly for the future development of sustainable and efficient catalysts employed in the cracking of oils. Up to date, the use of metal-impregnated catalysts in the conversion and upgrading of oils to valuable products has not been critically and comprehensively reviewed despite many studies reporting their usability and efficiency. This review thus seeks to provide an adequate understanding of the existing and emerging choice of composites for catalytic petrochemical processes; the composition, importance, limitations, areas of improvement, and sustainable approach to the development of metallic composites used in catalytic cracking in the petroleum industry.

\section{Ecological restrictions on quality characteristics of oils}

Technological advancement is steered as much by economics as well as government as it is by modernization. There is no superior example of this other than in the petroleum refining and process development. In the last decade, advancement in the petrochemical industry has been steered by increased global demand for petroleum products, need for process efficiency, enhanced product selectivity, segmentation of product via quality improvement, environmental concerns for sulphur content, improved aromatics, and olefins to assist an increasing but cyclical petrochemical sphere as well as improved manufacture of oxygenates to achieve the clean fuel directives $[31,32]$. These are presently being re-explored because of the increasing concern from the environmental circle of benefits and liabilities suffered by the compulsory incorporation of oxygenates in gasoline [2,33].

The ever-increasing demand for energy as well as environmental problems is part of the major implications of the rapid expansion of human society [34]. The major environmental issue in recent times has been air pollution, not undermining the damning impact of oil spillage on aquatic and terrestrial species [35]. It is a fact that the burning of petroleum products belches harmful gases and compounds into the atmosphere, resulting in the greenhouse effect, ozone depletion, and acute and/or chronic toxicities in living things. Crucial emissions of $\mathrm{NO}_{x}, \mathrm{SO}_{x}, \mathrm{CO}_{x}$, and particulate matter are the sources of the majority concern for environmental pollution [36]. To reduce their effect, stringent environmental restrictions have been launched in many developed countries across the globe to decrease the sulphur and aromatic contents in automobile fuels aimed at reducing harmful exhaust emissions and improving the quality of air [37].

Element with significant amounts in petroleum after carbon and hydrogen is sulphur. In crude oil, the average sulphur content varies from 0.03 to $7.89 \mathrm{~g} / \mathrm{g} \%[31,38]$. The sulphur compounds are usually found in two distinct forms of inorganic and organic. Present in the dissolved or suspended form is the inorganic sulphur like elemental sulphur, $\mathrm{H}_{2} \mathrm{~S}$, and pyrite. In the same vein, organic sulphur compounds like thiols, sulphides, and thiophene compounds constitute the main origin of sulphur found in crude oil [31]. Substantial attention has been directed towards identifying the sulphur compounds in heavy oils, oil sands, and derived bitumen [31]. New guidelines as proposed by the Environmental Protection Agency (EPA) in the year 2010 were to limit the sulphur in diesel fuels from low sulphur diesel (LSD) of $500 \mathrm{ppm}$ wt to ultralow sulphur diesel (ULSD) of less than 15 ppm. In Euro 
V standard, sulphur content of diesel fuels was restricted to be less than $10 \mathrm{ppm}$, in a bid to reducing the adverse effects of the consumption of fossil fuels [39].

Furthermore, worldwide fuel character introduced restrictions on the content of aromatics in diesel fuels to less than $20 \%$ in the advancing future. Undoubtedly, the decrease of emissions of exhaust gas [majorly hydrocarbons (HC) and particulate matter (PM)], as well as the improved Cetane Index (CI), is attributed to the reduction of the aromatics in diesel fuels [40, 41]. The increasing alertness of the effects on the pollution of the environment by automobiles has the responsibility of pollution control diverted to the refineries. The sulphur specifications for both gasoline and diesel are made more stringent as a consequence of their impact on the environment [42]. The demand for cleaner fuel has been on the increase, since the concerns for the environment have been emphasized. The strict restriction of heavy oils commonly utilized as combustion oils came as a consequence of the high percentages of sulphur it contains [43]. For that reason, it was envisaged that ultra-deep hydroaromatization and hydrodesulphurization of gas oils should be considered essential to meet both the market and environmental requirements [41].

The stricter environmental regulations linked with the rising dependence on heavy oils obtained from bitumen are the huge obstacles confronting the petroleum industries [44]. In the past years, there has been a reasonable increase in awareness about environmental protection, and consequently, a law limiting the sulphur contents in fuels has been enforced across the globe. At present, the reduction of environmental issues induced by the emissions of $\mathrm{SO}_{x}$ into the environment requires high-quality ultra-low sulphur transportation fuels. To this end, the hydrotreatment processes making use of more active and selective catalysts have been proposed [45].

The environmental laws regarding the standard of automotive fuels as well as the emissions from the refinery are presently the most vital and most costly issues. Pollutants, such as $\mathrm{SO}_{x}, \mathrm{CO}$, nitrogen oxides $\left(\mathrm{NO}_{x}, x=1,2 ; 90-95 \%\right.$ in the form of NO) [35], which are the main air pollutants produced by the burning of fuel in stationary and automotive engines, particulates, olefins, and aromatic hydrocarbons, are of major concerns [46]. The improvement in the environmental status of motor fuel is ascribable to the universal agreement in the legislation by many countries across the globe. In this regard, the reduction of the sulphur contents of diesel and gasoline in the advancing years is expected to be nearing 10 and $50 \mathrm{ppm}$ sequentially. A small degree of sulphur in transportation fuels will not only at-once better the standard of air by decreasing $\mathrm{SO}_{x}$ emissions, but will also indirectly reduce the $\mathrm{NO}_{x}$ and hydrocarbon emissions by permitting the better work of automotive catalytic converters $[47,48]$. As a result of the enacting demand for a radical decrease in the sulphur content of automotive fuels (say $30 \mathrm{ppm}$ in gasoline and $15 \mathrm{ppm}$ in diesel) that was fully enforced in 2009, much attention has been given to the deep desulphurization of transportation fuels in the research community globally. The emissions of $\mathrm{SO}_{x}$ in combustion gases were boosted by the sulphur in gasoline, thereby decreasing the activities of the catalytic converters of vehicles as well as promoting the corrosion of parts of the engine [49].

There has been a considerable rise in the demand for heavy oil feedstock for refinery aimed at manufacturing gasoline with low sulphur which is attributed to the stringent environmental promulgations in respect to fossil fuels [50]. The reinforcement of efficient hydrodesulphurization (HDS) catalysts has been steered by the requisite of manufacturing ultra-clean fuels for protecting the environment [51]. The production of clean gasoline with sulphur less than $10 \mathrm{ppm}$ is a burning topic with regards to eco-friendly catalysis [52]. There has been immense attention in recent years directed towards the deep hydrodesulphurization (HDS) of fuels obtained from petroleum due to the environmental requirements suggesting the need to eliminate sulphur. In recent times, low sulphur-containing transportation fuels (less than $10-15 \mathrm{ppm})$ are in use in many countries globally [53, 54]. The enactment and enforcement of laws and an increase in people's environmental protection awareness are accelerating advanced research into ultra-clean gasoline production.

\section{The use of hydrotreating in improving the quality of oils}

Hydrotreating or hydroprocessing encompasses different hydrogenation procedures that saturate unsaturated hydrocarbons accompanied by the removal of sulphur, nitrogen, oxygen, and metals through processes, such as hydrodesulphurization (HDS), hydrodenitrogenation (HDN), hydrodeoxygenation (HDO), and hydrodemetallization (HDM) from various streams of petroleum during refining. Hydrotreating of crude oil is mainly aimed at reducing the emissions of air pollutants, as well as avoiding poisoning of noble metals and acid catalysts utilized in catalytic reforming and cracking and the improvement of the quality of the fuel [46, 55]. The application of hydrotreatment in a hypothetical refinery is shown in Fig. 1. Hydrotreating is a non-destructive process useful for the improvement of product quality without appreciable change(s) in boiling range [56]. Hydroprocessing of the feed is a productive way not only to lessen the final sulphur content of liquid distillates; nevertheless, it equally promotes an increase in the yields of liquids, while enhancing the standard (cetane number) of the diesel, but reducing the octane number of the gasoline produced [47]. The main technologies employed for the desulphurization of heavy oil industrially are hydrodesulphurization (HDS) in 


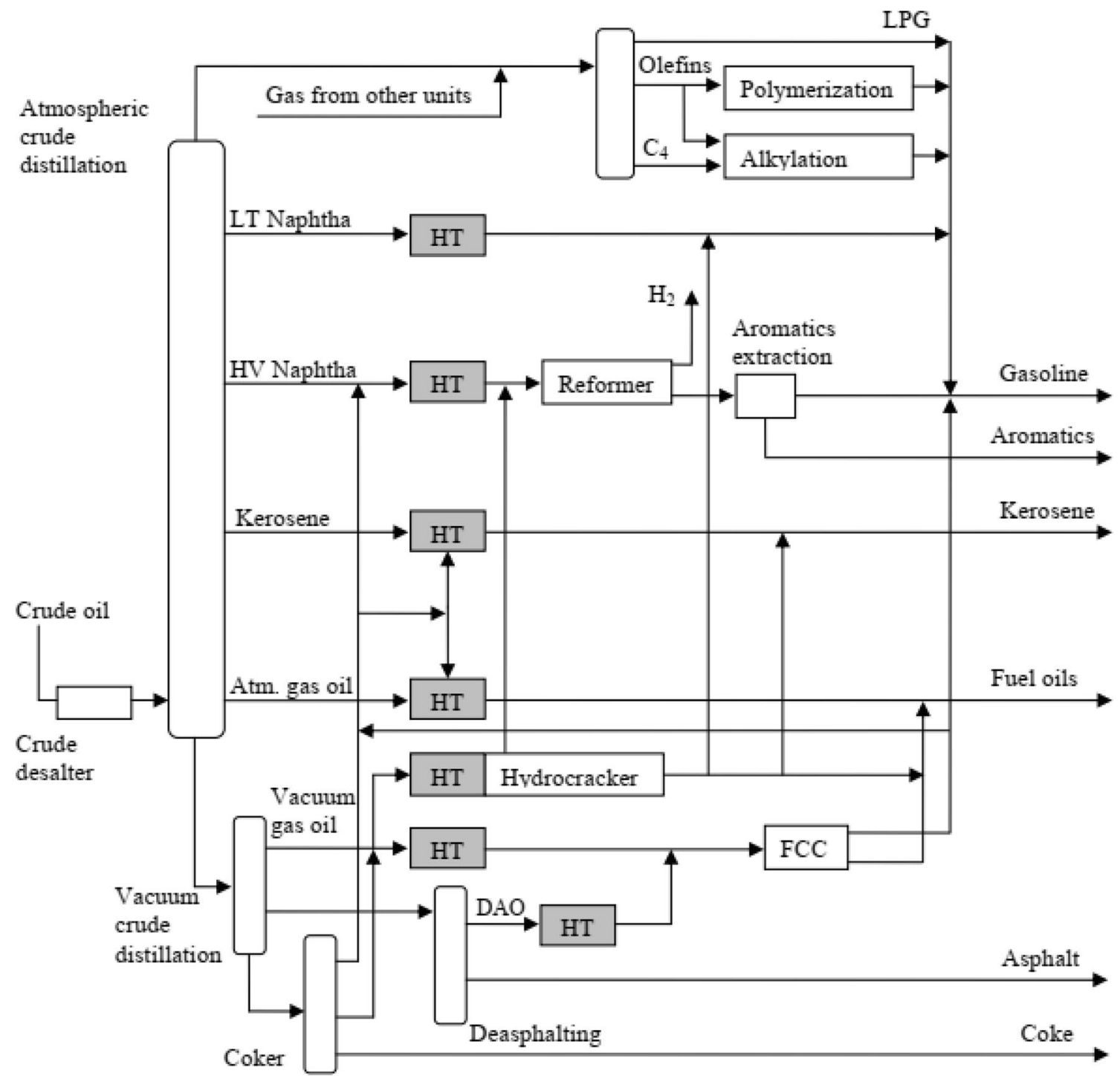

Fig. 1 Application of hydrotreatment (HT) in a hypothetical refinery [46]

combination with carbon rejection methods like coking and fluid catalytic cracking (FCC) [31].

The ever-increasing global attention received by the deep desulphurization of fuel oils was due to the more stringent sulphur regulations. Sulphur compounds present in fuels, as it is known caused severe environmental pollution as well as severe corrosion of reactors and equipment used in oil processing. The poisoning activities of sulphur in catalytic processes are undeniable. Thus, considering both the industrial and environmental effects of sulphur, the desulphurization of petroleum products is essential [57]. In the refining industry, the term hydrotreating, hydroprocessing, hydrocracking, as well as hydrodesulphurization are rather loosely used, since cracking and desulphurization operations occur concurrently in the hydrodesulphurization and hydrocracking processes and it is relative as to which stand out. Here, hydrotreating refers to a moderately mild operation whose principal goal is to decrease the sulphur content (and not to alter the boiling range) of the feed [58].

The most widely employed commercial technology is the catalytic hydrodesulphurization (HDS), apart from being efficient towards the removal of thiols, sulphides, and disulphides, it is not ideal for the removal of thiophenes specifically the alkyldibenzothiophenes [57]. A typical HDS unit is shown in Fig. 2. HDS is a catalytic procedure widely employed in the removal of sulphur from processed petroleum products like diesel fuel, gasoline, jet fuel, as well as fuel oils. The reason for sulphur removal is to decrease the emissions of $\mathrm{SO}_{2}$.

The reaction to the main HDS procedure is: 


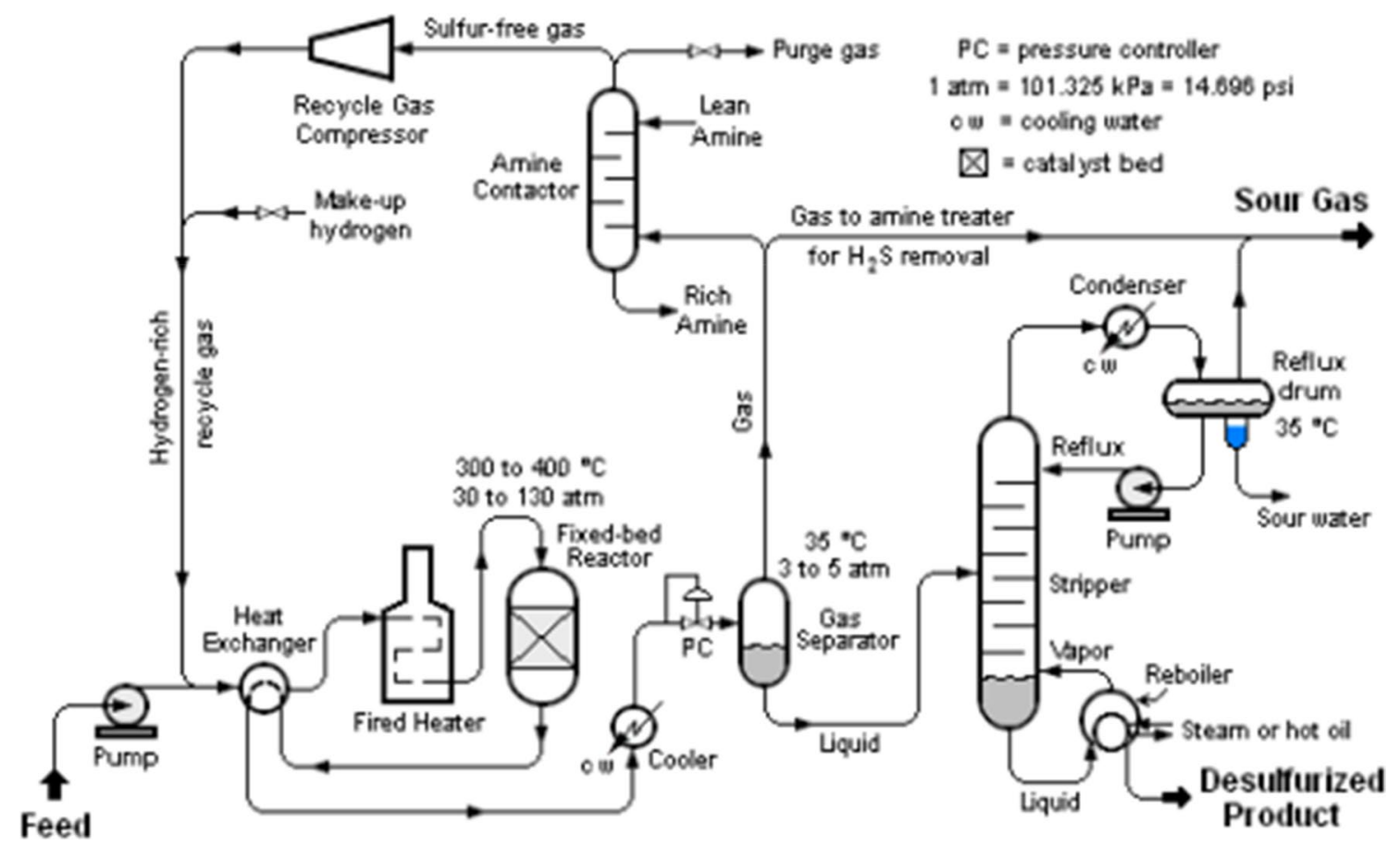

Fig. 2 A typical hydrodesulphurization unit [58]

Organic sulphur compound $+\mathrm{H}_{2(\mathrm{~g})} \rightarrow \mathrm{H}_{2} \mathrm{~S}_{(\mathrm{g})}$

+ desulphurized organic compound.

Sulphur-containing compounds react with hydrogen in the presence of a catalyst and get converted into hydrocarbons and hydrogen sulphide. Hydrogen sulphide produced and obtained is in the gas phase and it is being removed easily [59]. The HDS procedure entails the catalytic treatment with hydrogen to change the different sulphur compounds present into hydrogen sulphide. Here, some of the hydrogen sulphides are oxidized by air to form sulphur dioxide and the sulphur is thus removed by the following overall reaction:

$2 \mathrm{H}_{2} \mathrm{~S}+\mathrm{SO}_{2} \rightarrow 3 \mathrm{~S}(\mathrm{~s})+2 \mathrm{H}_{2} \mathrm{O}$.

The HDS is a representative of an essential component of the present petroleum refining operations in terms of environmental as well as economic considerations. Presently, crude oils are becoming heavier with rising amounts of sulphur. Since the size of the organic molecules in the heavy oil fractions is large, the HDS catalyst supports have primarily mesopores as well as micropores. Typical HDS catalysts contain CoMo or NiMo sulphides supported on alumina [60].

To achieve the sulphur specification as required by the strict regulations, it is imperative to embrace new technologies for the reduction of sulphur [61], and possible procedures like adsorption, extraction, oxidation, as well as bioprocess are used for ultra-deep desulphurization [57]. In the last few years, much attention has been given to ultra-deep desulphurization from diesel due to the stringent regulations of sulphur levels in many countries across the globe. At the moment, the development of varieties of desulphurization methods meant for the reduction of sulphurcontaining compounds to an ultra-low level from diesel fuel has taken place. One of the alternative methods meant for ultra-deep desulphurization is oxidative desulphurization (ODS). Here, the compounds containing sulphur like benzothiophenes (BT), dibenzothiophene (DBT), and 4, 6-dimethyl dibenzothiophene (4, 6-DMDBT) are oxidized to their corresponding sulphones which can be separated from the diesel using extractant and this achieved the ultra-deep desulphurization of diesel fuel [62]. The goal of the elimination of sulphur from petroleum products is to decrease the sulphur dioxide $\left(\mathrm{SO}_{2}\right)$ emissions that come from numerous combustion practices. Moreover, it is vital to remove sulphur from the naphtha streams within petroleum refinery, because, at extremely low concentrations, sulphur poisons the noble-metal catalysts (platinum and rhenium) in the catalytic reforming units that are subsequently utilized to improve the octane rating of the naphtha streams [58].

However, the design of improved catalysts for hydrotreatment is of predominant importance not only in the reduction of environmental pollution but also in process optimization for feedstocks of low grade [37]. The research and development circle has greeted these challenges with the

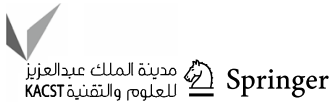


introduction of varieties of new catalytic processes and looking for ways of modifying many of the substantial refinery processes of manufacturing the fuels, lubricants, petrochemicals, as well as special products needed by a more valueconscious and environmental alert society. Many of these process innovations have come in place as a result of recent applications of zeolite catalysts [33]. This can be realized by developing more active or selective catalysts for the hydrotreatment (HDT) processes [63]. The core of the reforming process is the catalyst and most of the notable improvement in the process was attributed to the development of improved catalyst [64]. A specific catalyst used for the conventional hydrotreatment of crude oil includes shaped alumina-supported sulphided Mo promoted by either Co or Ni [65]. The regular process employed in removing heteroatoms as well as quality upgrading of petroleum in the refining industry is the catalytic hydrotreatment using supported Ni-Mo or Co-Mo catalysts, and for many decades, it has been commercialized [43].

The evolution of the newer generation of catalysts is essential to meet up with the challenges coupled with the HDS of numerous petroleum fractions. The improvement of the activity of the catalyst had experienced various attempts such as changes in the active metal composition, use of disparate types of active metals, supports, and additives, etc. among which the vital one is the variation of supports. Molybdenum promoted with cobalt and nickel supported on alumina makes up most of the HDS catalysts utilized for industrial applications [42]. Due to their introduction, 40 years ago, into the refinery, zeolite catalysts have been the origin of notable improvements in the yield of gasoline and octane along with the production of cleaner fuels and lubricants with enhanced performance properties [33].

Gamma alumina, $\gamma-\mathrm{Al}_{2} \mathrm{O}_{3}$, supported $\mathrm{NiMoS}$ and $\mathrm{CoMoS}$ are widely utilized for the hydrotreating of petroleum in oil refineries. The amelioration of the aforementioned catalysts is required given the greater environmental concern as a result of the pollution caused by automobiles as well as the subsequent limitations of the sulphur contents in gasoline and diesel fractions due to the stringent environmental regulations [66]. Platinum supported on gamma-alumina $\left(\mathrm{Pt} / \gamma-\mathrm{Al}_{2} \mathrm{O}_{3}\right)$ is a well-known reforming catalyst up to date; its interaction with sulphur is recognized. More importantly, sulphur can cause the modification of the reforming $\mathrm{Pt} / \gamma-\mathrm{Al}_{2} \mathrm{O}_{3}$ catalysts through the adsorption over the hydrogenolysis sites of the catalyst, consequently, altering the selectivity of the catalyst in reactions of olefins that are competitive, to which isomerization is preferred to reactions of hydrogenation and hydrocracking. The partial or complete removal of sulphur by hydrogen treatment made this effect reversible, although the poisoning of the catalyst is due to the remaining sulphur that is irreversibly held. Apart from their general use in naphtha reforming, platinum (Pt) catalysts were identified a long time ago as desulphurizing catalysts, which is advantageous. Specifically, the especially good hydrogenating ability of platinum $(\mathrm{Pt})$ makes it suitable as a potential catalyst meant for deep hydrodesulphurization (HDS) and hydroaromatization (HAD) [67]. Sulphided transition metals have been widely employed as hydrotreating catalysts. Hydrodesulphurization catalysts are predominantly little crystallites of sulphided Mo promoted with either $\mathrm{Co}$ or $\mathrm{Ni}$ and alumina as the support [68].

Pt and Pd, either as monometallic or alloyed catalysts, have demonstrated excellent catalytic activity in the hydrodesulphurization (HDS) of dibenzothiophene (DBT) molecules. 4,6-DimethylDBT is the common representative member belonging to the family of the highly refractory 4,6-alkyl-substituted DBTs, often referred to as the molecule of interest (target), to be hydropurified in heavy oil cuts. However, the HDS of this molecule can occur through the hydrogenation (HYD) or the direct desulphurization (DDS) routes. The steric hindrance imposed by the alkyl substituents of 4,6-dimethylDBT has been investigated both experimentally and theoretically, and they have been found to inhibit the scission of the sulphur heteroatom through DDS, consequently making the conversion through HYD salient to the achievement of the required HDS rate [69].

The developed catalysts for hydrotreating include tungsten and molybdenum sulphided on alumina. These metals are often referred to as hydrogenating catalysts; however, the addition of either sulphided cobalt or nickel caused the modification of their properties. Hydrogenation catalysts include nickel sulphide, nickel thio-molybdate, tungsten, and nickel sulphides, as well as vanadium oxide. Sulphided cobalt and molybdenum catalysts supported on alumina are to a great degree in use today; since they have proven to be tremendously selective, regeneration is undemanding, as well as been resistant to poisons [58]. Tungsten phosphide (WP) was studied, and it was found that it possessed high hydrogenation/dehydrogenation activity, but was highly sensitive to piperidine inhibition. The methyl groups suppressed the direct desulphurization of 4,6-DMDBT, but significantly promoted the hydrogenation of 4,6-DMDBT and the dehydrogenation of 1,2,3,4-tetrahydro-4,6-dimethyldibenzothiophene (TH-4,6-DMDBT) and 1,2,3,4,4a,9b-hexahydro4,6-dimethyldibenzothiophene, but decreased the rate of hydrogenation of TH-4,6-DMDBT (Fig. 3) [70].

Typically, there is a need to activate these metals by converting the hydrogenation metals from the oxide to the sulphide form, because they are usually in the oxide state when purchased. The catalysts meant for economical sulphur removal contains cobalt and molybdenum sulphides (CoMoS) supported on alumina. Nonetheless, if nitrogen 


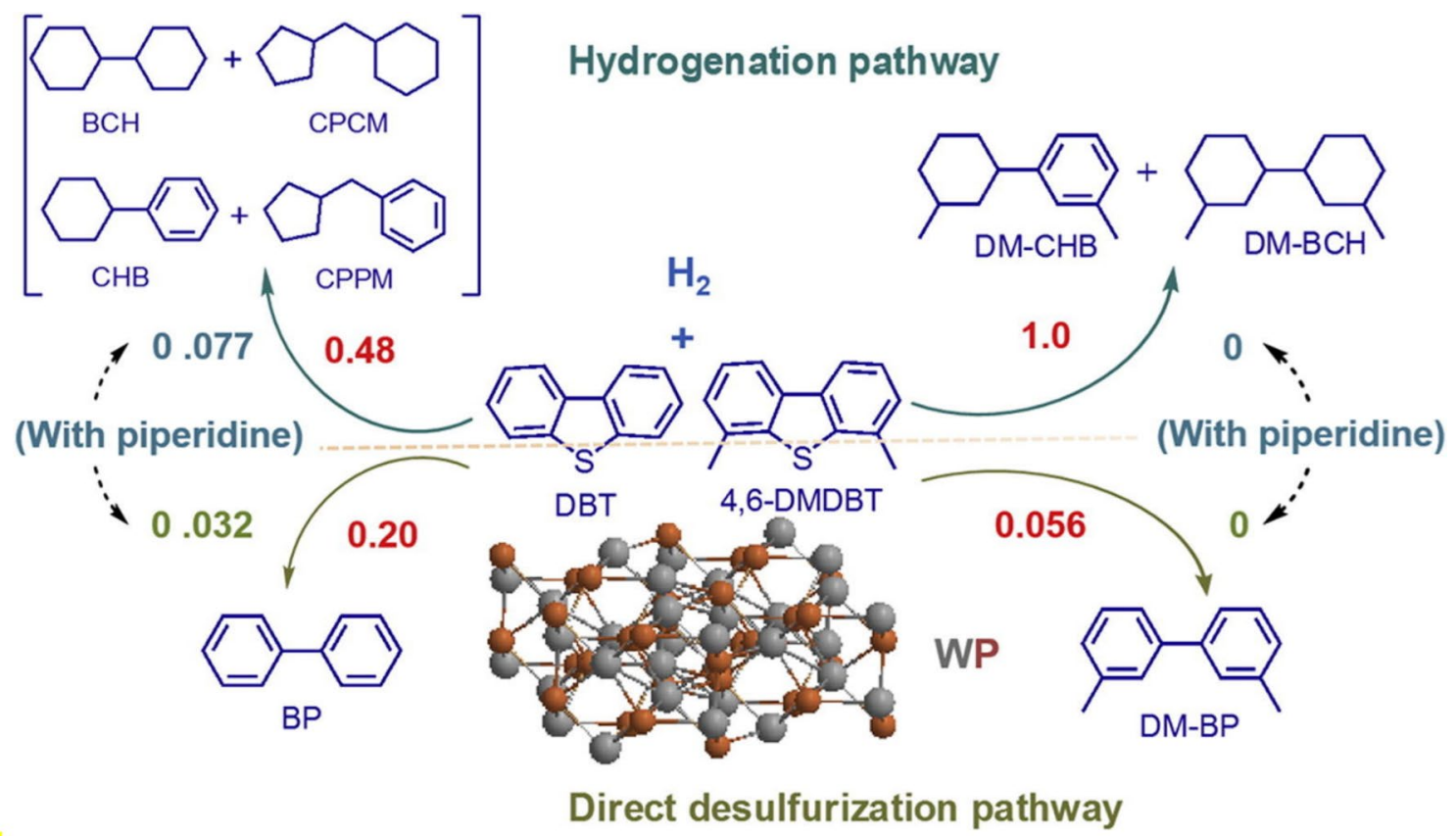

Fig. 3 Desulphurization mechanism and pathways ( Adapted from Yang et al. [70] Copyright 2015 Elsevier BV)

removal is of remarkable consideration, then the catalysts composed of nickel-cobalt-molybdenum or nickel-molybdenum (NiMo) compounds on alumina supports are more effective.

\section{Composition of metallic composites}

Metallic composites are materials with higher specific properties, e.g., stiffness, strength, etc., and less density. They exhibit upgraded properties emanating from combinations of two or more materials. The combination usually comprises of a matrix and a reinforcement; the former is responsible for distributing the applied stress, while the latter ensures the provision of the required mechanical strength [71]. Metallic composites are made through the dispersion of reinforcing material in a metal matrix [72]. Table 1 presents a summary of metal composites and supports to promote and expedite chemical processes involving the treatment of heavy/crude oils and conversion to useful, low-molecular-weight petrochemicals. There are two main components of new fluid catalytic cracking (FCC) catalysts which are zeolites and a matrix. Additionally, other catalysts also contained additives which boost octane number of gasoline, enhancing the resistance of catalyst to metal, sulphur dioxide $\left(\mathrm{SO}_{2}\right)$ emissions reduction, as well as the oxidation of carbon monoxide $(\mathrm{CO})$ [73].

The matrix is the monolithic material that the reinforcement is embedded, and is completely continuous.
The reinforcement surfaces are often coated to forestall a chemical reaction with the matrix. This means that there is a path through the matrix to any point in the material, unlike two distinct materials sandwiched together. The active catalytic component of a catalyst is carried by the catalyst matrix material [74]. Outstandingly, the active matrix ensures an extensive performance of the FCC catalyst by pre-cracking sizeable oil molecules to enhance penetrability to the zeolite's micropores. The inert portion of the matrix, referred to as filler, generally functions as a heat sink and transfer medium as well as providing little or no catalytic activity to the catalyst. For optimum fluidization properties, the filler also offers mechanical strength and improves the apparent bulk density (ABD) of the particle. The binder mainly acts as a glue, jointly binding zeolite, matrix, and the filler as well as providing huge attrition resistance. The binder occasionally modifies the coking attributes and acts as an inhibitor for poison species [75]. Additionally, the matrix in many commercial catalysts is the amorphous silica, alumina, or silica-alumina. Concerning the matrix's catalytic roles, it is principally responsible for the catalyst's physical properties [73].

The multifaceted structure and composition of metallic composites are reasons why they exhibit complex behaviour. The stability, activity, and selectivity of the metallic composite catalyst are predicated upon the intrinsic activity and localization of the acid sites and the metal [76]. The proximity of the metal and acid sites, a phenomenon described as "site intimacy", affects the selectivity of the reaction. Mechanical mixing and impregnation are the

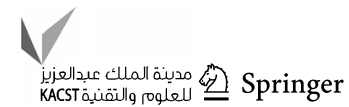


Table 1 Summary of various catalyst and supports used for cracking and desulphurization processes

\begin{tabular}{|c|c|c|c|}
\hline Composites used & Process involved & Treatment of & References \\
\hline $\begin{array}{l}\text { Ag-modified mesoporous molecular sieves (Ag/ } \\
\text { Ti-HMS) }\end{array}$ & $\begin{array}{l}\text { Oxidative desulphurization (ODS) of } \\
\text { benzothiophene }\end{array}$ & Heavy oils (crude) & {$[57]$} \\
\hline $\begin{array}{l}\text { Cobalt-molybdenum loaded on alumina support } \\
\left(\mathrm{CoMo} / \mathrm{Y}^{-} \mathrm{Al}_{2} \mathrm{O}_{3}\right)\end{array}$ & Hydrodesulphurization (HDS) & Crude oil & {$[42]$} \\
\hline Iron oxide-based catalysts & Catalytic cracking & Residual and heavy oil & {$[105,106]$} \\
\hline Mobil composition of matter number 41 (MCM-41) & HDS and cracking & Crude oil & {$[97,98]$} \\
\hline $\begin{array}{l}\text { Nickel-molybdenum (NiMo) catalysts supported on } \\
\text { MCM-41 }\end{array}$ & HDS & Heavy aromatic compounds & {$[101,102]$} \\
\hline $\begin{array}{l}\text { Hexagonal mesoporous silica (HMS), Santa Barbara } \\
\text { amorphous (SBA-15), and mesoporous } \mathrm{Al}_{2} \mathrm{O}_{3} \\
\text { systems }\end{array}$ & Cracking and HDS & Crude oil & {$[42,95,96]$} \\
\hline NiMo/Al-SBA-15 & HDS and HDN & Light gas oil & {$[66]$} \\
\hline Vanadium (V) modified kaolin catalyst & HDS & Oils & [49] \\
\hline $\mathrm{Na}_{2} \mathrm{SiO}_{3} / \mathrm{SiO}_{2}$ & Transesterification reaction for biodiesel & Rubber seed oil & {$[103,104]$} \\
\hline $\begin{array}{l}\text { Metal-loaded zeolite: H-ZSM5, Cu-HZSM5, Zn- } \\
\text { HZSM5, and Mg-HZSM5 }\end{array}$ & Catalytic cracking & Palm oil and soybean & {$[17,18]$} \\
\hline Zeolite/alumina catalysts & Dehydration & Methanol to olefin & {$[107,108]$} \\
\hline Zeolite Y nanoparticles & Catalytic cracking to produce light crude & 1,3,5-Triisopropylbenzene (TIPB) & {$[73]$} \\
\hline Activated iron oxyhydroxide & HDS & Oil feedstock & [110] \\
\hline Composite zeolite beta-catalyst & Catalytic hydrocracking & Plastic wastes to liquid fuels & [113] \\
\hline $\mathrm{M}-\mathrm{Ni} / \mathrm{SiO}_{2}$ aerogel catalysts & Cracking & $n$-Decane & [114] \\
\hline UiO-66-Y metal-zeoliteloaded catalyst & Catalytic cracking & $\begin{array}{l}\text { Generating naphtha and diesel oil } \\
\text { from coal tar oil }\end{array}$ & [115] \\
\hline
\end{tabular}

two commonly employed methods of synthesizing metallic composites [77].

\section{Support for metallic composites}

Presently, the use of new materials as supports for catalysts is one of the numerous efforts aimed at improving the activity of catalysts [78-80]. The most relevant advances in the history of catalytic cracking were the introduction of porous materials as fillers and supports, specifically zeolites and clay, in commercial FCC catalysts in the early 1960s [81, 82] for various industrial processes [83]. With little capital investment, zeolite catalysts provided a greater profit [81], cost-effective, and environmental benefits such as the replacement of low-selective harmful mineral acids and chloro-containing catalysts, improved selectivity and yields of reactions, products' quality, and the catalytic systems' overall life, as well as the reduction of the energy consumption at the same time $[2,83]$. The zeolite catalysts have high activity as well as selectivity when compared to amorphous silica-alumina catalysts. However, this higher activity and selectivity implied a more profitable yield of liquid products and additional cracking capacity [82]. Improvement in catalytic efficiency and stability led to growing scientific interest and research into the development of novel materials and advanced framework architecture [84-86].

For a long time, the value of the support for catalysts used in HDS has been known, as well as the activities of supports like $\mathrm{SiO}_{2}, \mathrm{MgO}, \mathrm{ZrO}_{2}, \mathrm{TiO}_{2}$, and others has been extensively studied [87, 88]. The use of mixed supports has been proposed to repress these catalytic setbacks such as a tendency for poisoning, instability, etc. [89]. Catalysts made with amorphous silica-alumina supports have demonstrated better results in the HDS of 4,6-DMDBT connected to increased acidity and fewer surface hydroxyls attached to tetrahedral aluminium [68]. Thus far, the problem that has attracted extensive research efforts has been the efficiency and deactivation of the catalyst. The support's pore structure and the interaction between the active phases and the support are the two most important factors affecting the efficiency and stability of most catalysts. Jointly, these two factors influenced the active components' dispersion, their reducibility, as well as sulphidability, and the substrate molecule's accessibility to the catalytic sites. Thus, the vital problem made more crucial by the strict regulations concerning the permissible sulphur level in fuels is the discovery of good support for the Ni-Mo catalysts [5, 44, 90]. The only known support utilized in industrial HDS catalysts is $\gamma-\mathrm{Al}_{2} \mathrm{O}_{3}$. Various studies have been intensified on many other supports such 
as $\mathrm{SiO}_{2}$, carbon oxides, and mixed oxides, while the promising materials being mesoporous silica oxides which are used as support possessed an ordered mesoporous framework [50].

Alumina-based supports have proven to be the common supports for the hydrotreatment (i.e., hydrodesulphurization) of petroleum [91], as heterogeneous catalysts as well as sorbents for huge molecules [78]. The introduction of metal oxides as supports which investigated the catalytic activities of the sulphided CoMo catalysts and their consequent dependence on the nature of the support and additives incorporation is not new [91]. Many materials have been employed as supports for HDS catalysts [43, 92], having acidic or basic sites such as carbon, alumina, mixed oxides, and porous materials. The most applicable ones reported so far include $\mathrm{Al}_{2} \mathrm{O}_{3}, \mathrm{SiO}_{2}, \mathrm{ZrO}_{2}, \mathrm{TiO}_{2}, \mathrm{MgO}$, as well as mixed oxides among others [45]. Molybdenum-based catalysts have been known for ages to interact strongly with alumina supports. The interaction occurring between the active-phase and the support potentially affected the spread of the catalytic material and its reducibility and sulphidability, and thus, attention has been directed towards the investigation of alternative supports.

The formation of nanocomposite materials via the introduction of catalytic active species into a matrix is an aspect of catalysis with growing interest [54]. The nanocomposites' surface properties have been linked to their functionality, including surface-to-bulk atomic ratio, polyhedral surface framework, surface defects' concentrations (coordinatively ions that are unsaturated due to planes, edges, corners, anion/cation vacancies, and electron excess centers), surface acid-base strength, as well as shape selectivity [93]. In recent times, much attention has been given to zeolites such as ultrastable Y zeolite (USY) and mesoporous materials like Mobil Composition of Matter number 41 (MCM-41), hexagonal mesoporous silica (HMS), Santa Barbara Amorphous (SBA-15), and mesoporous $\mathrm{Al}_{2} \mathrm{O}_{3}$ systems [42, 94, 95]. For instance, it was experimented that CoMo or NiMo catalysts supported on MCM- 41 are better catalysts when compared to the commercial alumina-supported Co-Mo, $\mathrm{Ni}-\mathrm{Mo}$ catalysts employed for desulphurization [43, 78]. The higher catalytic activities of CoMo supported on MCM41 were reported for the conversion of benzothiophene and petroleum residues as well as being more substantially active than $\mathrm{CoMo} / \gamma-\mathrm{Al}_{2} \mathrm{O}_{3}$ catalysts at high molybdenum loadings. The relatively higher catalytic activity reported in the study was attributed to the uniform and regular pore structure of the tubular-shaped MCM-41 as opposed to the unimodal pore structure of $\gamma-\mathrm{Al}_{2} \mathrm{O}_{3}$. This finding is expected to help direct future research into the application of MCM-41 as catalyst support for smaller molecules $[91,96]$. The findings of the study showed that the use of chelating agents during the preparation of catalyst increases its pore diameter, providing better stability for the catalyst in the process.

The discovery of many other types of ordered mesoporous materials such as HMS, KIT, FSM-16, as well as SBA types have been reported $[97,98]$. With a variety of templates, these materials synthesized in either acidic or basic media offered the opportunity to synthesize materials with a tunable pore size [99]. However, materials like MCM-41 have been found to possess poor hydrothermal stability which presents a pressing restriction to their applications [66]. A proposed configuration for hydrogen production from the fuel cell is shown in Fig. 4 [100]. To improve the thermal stability of these materials, the wall thickness must be increased $[43,99]$. In addition to an increased wall thickness, the introduction of heteroatoms such as aluminium and titanium into the material framework could also bring about an improvement in the material's thermal stability.

\section{Benefits, limitations, and effects of catalytic activities of metallic composites in cracking reactions}

Herrera et al. [101] reported the hydrodesulphurization of dibenzothiophene (DBT) and 4,6-dimethyl dibenzothiophene (4,6-DMDBT), using NiMo catalyst supported on MCM-41 having $2 \mathrm{wt} \% \mathrm{P}_{2} \mathrm{O}_{5}$. They concluded that the

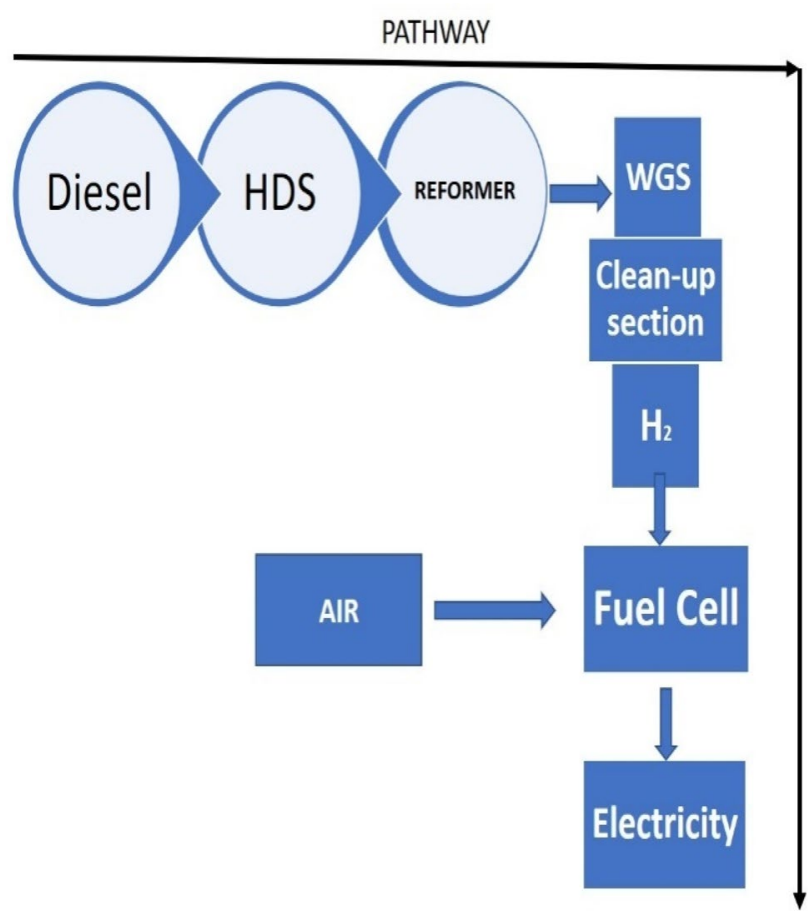

Fig. 4 Proposed configuration for hydrogen production and electricity from diesel fuel [100] 
catalyst was moderately more active than other NiMo catalysts containing phosphorus. The NiMo/MCM-41 catalysts demonstrated a higher catalytic activity in 4,6-DMDBT HDS than the $\mathrm{NiMo} / \mathrm{Al}_{2} \mathrm{O}_{3}$ used as reference material. Consequently, it can be deduced that the modification of MCM-41 with phosphorous produced high-performance NiMo catalysts chiefly for dibenzothiophene compounds. The analysis of the yield of the product revealed that the inclusion of phosphorus boosts the hydrogenation pathway of HDS [102]. The modified phosphorus mesoporous molecular sieves demonstrated reassuring attributes as supports for Mo-based hydrotreating catalysts ideal for the removal of refractory sulphur compounds like 4,6-DMDBT [101]. The production of clean energy fuels would be greatly facilitated by the use of phosphorus-modified catalysts, particularly as it aids the hydrogenation pathway of hydrodesulphurization during upgrading.

The conversions of $\mathrm{N}$ and $\mathrm{S}$ of NiMo/SBA-15 catalysts at regular state conditions are shown in Fig. 5. The HDS, as well as HDN activities gotten with NiMo, supported on siliceous SBA-15, are not as effective as their boron or alumina-supported equivalents. This perhaps was due to a very feeble interaction of Mo and the siliceous support that does not afford large dispersion of the sulphided molybdenum kinds. Both conversions of $\mathrm{N}$ and $\mathrm{S}$ are significantly increased with a rise in Mo loading from 7 to $12 \mathrm{wt} \%$. When Mo loading was further increased to $17 \mathrm{wt} \%$, there was an extensive increase of $\mathrm{N}$ conversion, whereas the $\mathrm{S}$ conversion was improved slightly. On increasing Mo loading to $22 \mathrm{wt} \%$, there was no significant improvement in both HDS and HDN activities of NiMo/Al-SBA-15. From their studies, it was evident that NiMo/Al-SBA-15 catalyst having

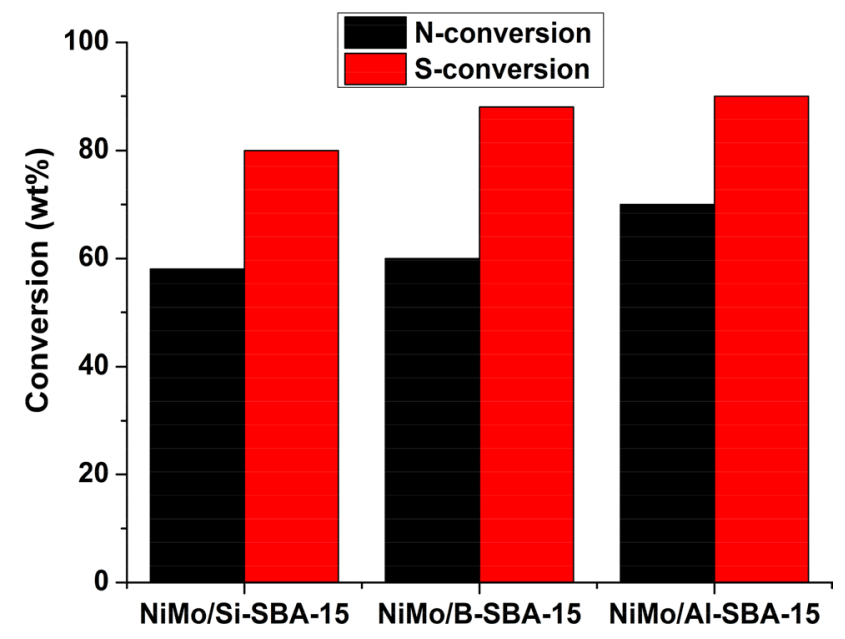

Fig. 5 Comparison of HDN and HDS functionalities of Si-SBA-15, B-SBA-15, and Al-SBA-15 supported NiMo catalysts. Feed $=$ LGO, $T=370{ }^{\circ} \mathrm{C}, P=8.8 \mathrm{MPa}$, WHSV $=4.5 \mathrm{~h} 1$, and $\mathrm{H}_{2} /$ oil ratio $=600(\mathrm{v} / \mathrm{v})$ (adapted with modification from Sundaramurthy et al. [66] Copyright 2008, Elsevier BV)
$17 \mathrm{wt} \%$ Mo is the most potent catalyst for both HDN and HDS of light gas oil (LGO) [66]. It can be concluded that the catalytic investigation of LGO using Al-SBA-15 supported NiMo catalyst with varying loadings of Mo demonstrated that $17 \mathrm{wt} \%$ of Mo loaded catalyst is preferable and more efficient.

Dai et al. [49] reported the sulphur reduction in FCC making use of kaolin in situ crystallization catalyst modified with vanadium. The modification by vanadium(V) of kaolin in situ crystallization catalyst increased the total acidity of the kaolin, and it enhanced the weak Lewis acidity. The crystal structure of the catalyst was not damaged by vanadium. Thus, the reduction in the activity of the catalyst was not significant. There was an increase in the weak Lewis acidity which was as a result of the increase in its vanadium content, thus leading to an enhancement in the extent of reduction of sulphur content. The kaolin modified with $0.6 \mathrm{wt} \%$ vanadium gave a sulphur reduction of $34.5 \%$ in the sulphur content of the liquid product, while the modified kaolin with $0.45 \mathrm{wt} \%$ vanadium gave the best performance [49]. While it is important to carefully consider the choice of metals used in catalyst modification due to potential toxicity, a relative upsurge in the \% wt of metals in catalyst composites would significantly aid the desulphurization processes of conventional and unconventional oils.

$\mathrm{Na}_{2} \mathrm{SiO}_{3} / \mathrm{SiO}_{2}$, a solid alkaline heterogeneous catalyst that is readily affordable and caused a reduction of the disadvantages of conventional homogeneous catalysts, having enhanced activity for transesterification reaction of rubber seed oil, was used for the production of biodiesel from rubber seed oil. Because of its solid phase nature, it demonstrated its obvious advantages as well as high activity in the regeneration of the catalyst $[103,104]$. The study revealed

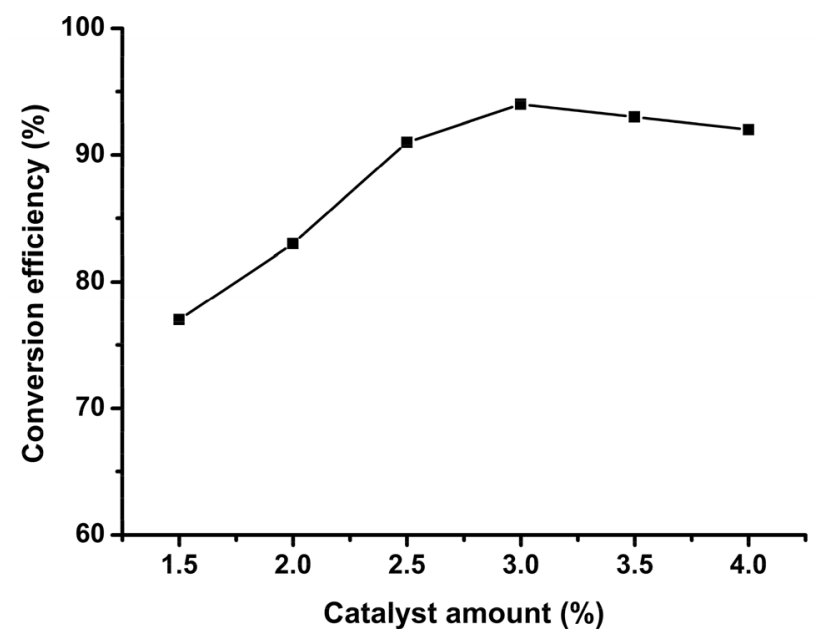

Fig. 6 The effect of the amount of catalyst on conversion efficiency (adapted with modification from Nguyen et al. [103] Copyright 2010, Springer) 
that the amount (in percentage) of the catalyst used affected the conversion efficiency of the rubber seed oil (Fig. 6). By and large, the increase in the amount of the catalyst gave rise to the conversion efficiency, because more active sites are available. The highest conversion was observed using 3\% weight of the catalyst, while further catalyst addition did not affect the conversion efficiency but rather led to saponification as well as energy wastage $[19,103]$. The biodiesel produced from rubber seed oil with $\mathrm{Na}_{2} \mathrm{SiO}_{3} / \mathrm{SiO}_{2}$ was of better quality as seen from its properties (Table 2), in comparison with the ASTM standard for biodiesel. The use of $\mathrm{SiO}_{2}$ as support created a well-pored structure for the catalyst and aided the efficiency of its regeneration.

The catalytic cracking of used palm oil (UPO) as reported by Chang and Tye [17] was experimented using four catalysts; H-ZSM5, Cu-HZSM5, Zn-HZSM5, and Mg-HZSM5 at a reaction temperature of $350{ }^{\circ} \mathrm{C}$ for $1 \mathrm{~h}$. Mg-HZSM5, among the three metal-loaded zeolite catalysts, gave the highest yield of liquid product $(84.7 \mathrm{wt} \%$ ) and gasoline fraction of $8 \mathrm{vol} \%$, as shown in Table 3. With the conversion of $26.74 \mathrm{wt} \%$, Zn-HZSM5 catalyst gave the highest conversion. The ratio of mesophase to microphase in the composite catalyst performed a vital role in raising the gasoline fraction and conversion in the catalytic cracking of UPO and soybean $[17,18]$. A reduction in this ratio caused a corresponding increase in the gasoline and conversion of UPO. It can be inferred that a composite catalyst having $5 \mathrm{wt} \%$ of magnesium was found to be the most active in the catalytic cracking of the UPO.
The desulphurization of heavy oil with iron oxide-based catalysts using steam was studied in the catalytic cracking of atmospheric residual oil (AR) by Fumoto et al. [105]. The reaction was performed at $748 \mathrm{~K}$ in a fixed-bed reactor at atmospheric pressure. There was an increase in the yield of hydrogen sulphide with a higher ratio of steam to feedstock, whereas in the catalytic cracking of AR without steam, the hydrogen sulphide produced was minimal $[105,106]$. There was a reduction in the concentration of sulphur of oil to half of the corresponding feedstock, while some sulphur compounds were deposited on the catalyst. Oxidative cracking of heavy oil making use of oxygen species obtained from steam produced hydrogen species from steam, part of the hydrogen reacted with the heavy sulphur compounds present on the catalyst to produce hydrogen sulphide, light sulphur compounds, and hydrocarbons. Carbon dioxide as well as hydrogen sulphide were obtained when dibenzothiophene was decomposed using the catalyst. Therefore, both cyclic as well as acyclic sulphur compounds were decomposed using the catalyst and steam [105].

Hajimirzaee et al. [107] studied the effect of the reaction conditions, catalyst support, as well as zeolite modification in the dehydration of methanol to light olefins upon zeolite/alumina catalysts in a fixed-bed reactor. The production of light olefins more selectively is dependent on the high temperature of $400{ }^{\circ} \mathrm{C}$; however, elevated temperatures led to the deactivation, selectivity towards alkanes as well as lower selectivity to light olefins. The study revealed that huge concentrations of water in the feedstock resulted in
Table 2 The properties of biodiesel from rubber seed oil [103]

\begin{tabular}{llll}
\hline Property & Testing procedure & $\begin{array}{l}\text { Biodiesel standard ASTM } \\
6751-02\end{array}$ & $\begin{array}{l}\text { Rubber seed } \\
\text { oil methyl } \\
\text { ester }\end{array}$ \\
\hline Specific gravity & ASTM D4052 & $0.87-0.9$ & 0.882 \\
Calorific value $\mathrm{MJ} / \mathrm{kg}$ & ASTM D240 & - & 37.00 \\
Viscosity, $\mathrm{mm}^{2} / \mathrm{s}$ at $40^{\circ} \mathrm{C}$ & ASTM D445 & $1.9-6.0$ & 5.52 \\
Flash point ${ }^{\circ} \mathrm{C}$ & ASTM D93 & Min. 130 & 130 \\
Cloud point ${ }^{\circ} \mathrm{C}$ & ASTM D2500 & -3 to 12 & 4 \\
Pour point ${ }^{\circ} \mathrm{C}$ & ASTMD97 & -15 to 10 & -8 \\
Acid value $\mathrm{mg} \mathrm{KOH} / \mathrm{g}$ & ASTM D974 & 0.8 & 0.22 \\
\hline
\end{tabular}

Table 3 Performance of different catalyst on catalytic cracking of UPO [17]

\begin{tabular}{|c|c|c|c|c|c|}
\hline & $\begin{array}{l}\text { Liquid prod- } \\
\text { uct (wt } \% \text { ) }\end{array}$ & Residue (wt\%) & Coke (wt $\%)$ & Gases (wt \%) & $\begin{array}{l}\text { Conver- } \\
\text { sion } \\
(\mathrm{wt} \%)\end{array}$ \\
\hline UPO without catalyst & 72.11 & 11.24 & Negligible & 16.65 & 1.19 \\
\hline HZSM-5 & 83.28 & 10.46 & 0.48 & 6.26 & 22.67 \\
\hline $\mathrm{Cu}-\mathrm{HZSM}-5$ & 80.60 & 10.81 & 0.35 & 8.59 & 15.68 \\
\hline Zn-HZSM-5 & 75.94 & 8.20 & 0.06 & 15.80 & 26.74 \\
\hline Mg-HZSM-5 & 84.70 & 9.65 & 0.37 & 5.63 & 14.50 \\
\hline
\end{tabular}


higher production of light olefins, and catalytic selectivity to propene and other light olefins was enhanced with the use of $\gamma$-alumina as support. Zeolite catalyst having $25 \mathrm{wt} \%$ of ZSM-5 present in the sample of the catalyst resulted in maximum selectivity to propene and light olefins, but faster deactivation of these catalysts was noticed $[107,108]$. The modification of ZSM-5 zeolite with $\mathrm{P}, \mathrm{Cs}, \mathrm{Ca}$, and Fe led to an increase in shape selectivity to propene in all cases. The exchange of ZSM-5 zeolite ion by Cs resulted in optimal selectivity to propene through the changing of the acid site distribution. The least selectivity to $\mathrm{C}_{5+}$ compounds as well as the smallest quantity of coking was noticed on this catalyst.

The application of novel zeolite $\mathrm{Y}$ nanoparticles in fluid catalytic cracking (FCC) reactions was reported [73]. Crystalline nanoporous materials such as zeolites are used for a variety of applications in the industries. They possess distinguished properties like huge surface area, uniform porosity, accessible pore volume, large adsorption capacity, ion exchange capacity, and improved catalytic activity, based on shape and size; they are selective, etc. The parent zeolite nanoparticles were synthesized and the catalytic cracking experiments of 1,3,5-triisopropylbenzene (TIPB) were carried out in a laboratory-scale novel riser simulator at $400{ }^{\circ} \mathrm{C}$ using nitrogen as the carrier gas. Selectivity towards the production of light hydrocarbons was observed with the use of zeolite Y nanoparticles. Significant conversion was recorded when catalysts containing average sizes of 150 and $450 \mathrm{~nm}$ nanoparticles were used. The study indicated the feasibility of developing nanocatalysts with stable structures.

The effect of the method employed in the preparation of Ag-modified Ti-HMS catalyst, especially as it affects its structure and catalytic oxidative desulphurization performance was reported by Wang et al. [57]. Ag-modified mesoporous molecular sieves Ti-HMS were synthesized in situ (Ag/Ti-HMS-I), deposition-precipitation method (Ag/Ti-HMS-D), as well as impregnation assisted by ultrasound process (Ag/Ti-HMS-U), respectively. The catalysts' performances in the oxidative desulphurization (ODS) of benzothiophene with hydrogen peroxide $\left(\mathrm{H}_{2} \mathrm{O}_{2}\right)$ were studied. Experimentally, the results revealed that the $\mathrm{Ag}$ / Ti-HMS-U catalyst demonstrated the best activity and this was attributed to the mesoporous structure which was relatively good as well as the huge Ag dispersion [57, 109]. The efficiency of oxidative desulphurization for the removal of aromatic thiophenes, as opposed to catalytic hydrodesulphurization, was reflected in the method's high selectivity and mild reaction conditions. Ag/Ti-HMS-U catalysts prepared via ultrasound-assisted impregnation have enormous potential in the removal of sulphur from crude and heavy oils, in a bid to meeting the stern environmental regulations. However, oxidative desulphurization processes are relatively more expensive due to the use of oxidative reagents and/or high-energy intensity.

Andrienko et al. [110] reported the study on the removal of sulphur-containing compounds from fuel oils using a naturally occurring iron oxyhydroxide. Studies have shown that water deferrization waste like iron oxyhydroxide could be used as catalysts for the removal of sulphur-containing compounds (SCC) present in fuel oil through the oxidative desulphurization process. The iron oxyhydroxide was activated via heat treatment. However, the maximum parameters of the oxidation process were obtained; each time, SCC was removed from the fuel oil in the oxidative desulphurization process $[31,111]$. During this process which consisted of successive stages, the degree of desulphurization obtained for the fuel oil was $92.3 \%$ as a result of the successive SCC removal from the fuel oil during the various stages of oxidation of SCC as well as the extraction of the oxidized SCC present in the fuel oil [110]. The removal of sulphur-containing compounds from the oil feedstock making use of iron oxyhydroxide as a catalyst through oxidative desulphurization could be in huge demand for industrial uses due to the high catalytic activity of this readily available low-cost catalyst in the oxidation processes.

Feedstock recycling is receiving growing awareness due to environmental concerns. Contingent upon this, the conversion of plastic wastes to gasoline range fuels is gaining attention. If not properly guided, the financial costs of these conversion processes may not be economical. Hence, the need arises for the development of efficient, yet cost-effective catalysts to facilitate the conversion processes. Sequel upon this, Qureshi et al. [112] used a composite catalyst comprising modified Asian clay and pure metallic nanoparticles for the pyrolysis of plastics into liquid fuels in an autoclave reactor under varying reaction conditions. As opposed to the sole use of clay as a catalyst, the nickel-incorporated composite catalyst gave a maximum liquid yield of $79 \%$. This was believed to be facilitated by the increased surface area of the composite catalyst. The properties of the resulting liquid yield satisfied fuel specifications.

The conversion of plastic wastes to liquid fuels was carried out in a stirred autoclave reactor via catalytic hydrocracking using a composite zeolite beta-catalyst. The catalytic activity of fresh catalysts and the regenerated composite zeolite beta-catalysts (BC27 and $\mathrm{BC} 48$ ) were compared under reaction temperature conditions between 360 and $400{ }^{\circ} \mathrm{C}$. Catalytic experiments indicated that $93 \mathrm{wt} \%$ conversions were achieved at $400{ }^{\circ} \mathrm{C}$ using $\mathrm{BC} 27$ and $\mathrm{BC} 48$, as opposed to the fresh catalysts [113]. The regenerated composite zeolite beta-catalysts are a blend of microporosity and mesoporosity. The character of the former demonstrates excellent production of gases, while that of the latter favours the high liquid production. The synthesized composite zeolite 
beta-catalysts embodied high catalytic stability in the catalytic pyrolysis of plastic wastes to oils.

Wang et al. [114] investigated the catalytic activity of a series of $\mathrm{M}-\mathrm{Ni} / \mathrm{SiO}_{2}$ aerogel catalysts in the cracking of $n$-decane under temperature conditions of $600-750{ }^{\circ} \mathrm{C}$. Upon comparison with conventional wall-coated catalysts, the $\mathrm{M}-\mathrm{Ni} / \mathrm{SiO}_{2}$ aerogel catalysts showed better anti-coking and catalytic activity. Catalyst dosage of only half of the wallcoated catalysts produced these excellent results. The excellent textural properties of aerogel catalysts such as large specific area, low density, and high-temperature resistance are fast widening their popularity as catalyst supports. The use of aerogel catalysts could be further extended to the catalytic cracking of heavier hydrocarbons due to their performance.

The potential of generating naphtha and diesel oil from coal tar oil informed the investigation of the catalytic cracking of coal tar in a low-temperature distillation by aluminium retort using metal-loaded UiO-66 and Y-type zeolite. Both catalysts were synthesized using microwave-assisted and solution thermal methods. The combination of the catalysts resulted in UiO-66-Y metal-loaded catalyst. The use of the composite catalyst ensured the active decomposition of aromatic compounds in coal tar as well as the synthesis of a wide range of light component esters. The study concluded that the composite catalyst has advantages of both molecular sieve materials (high-temperature resistance) and metal-organic frameworks (low density) [115]. The current global energy quagmire may soon be a forgotten episode upon further investigation into improvement technologies of composite catalysts, with particular emphasis on stability.

\section{Sustainability of metallic composites}

In the quest for improved catalytic efficiency, cost reduction of chemical processes, and environmental concerns, significant advancement in material development has taken place in the last 2 decades [3]. The developments of recyclable/ regenerable, sustainable, and eco-friendly metal composite materials have attracted attention and explored globally [2, 116-118]. Composite development gravitated towards the use of efficient materials, which include metal-based alloys, polymeric composites, and metal-organic frameworks (MOF) [84]. Green metal-based composites with significant catalytic properties have been synthesized with plantassisted processes, as biochemical, environmental-friendly, and cost-effective alternative synthetic routes [119].

Metal-based catalysts have been embedded/loaded on solid supports to improve interfacial activity and reduce the loss of catalyst, which can be classified as a sustainable approach [84, 116]. In the past, carbon-based materials have been harnessed as supports for heterogeneous catalyst, due to high specific surface areas, adjustable porosity, and stability (Fig. 7). However, the emergence of N-doped carbonsupported metal catalysts in the last decade has attracted significant attention in catalysis, and the fact that nitrogen doping can be tailored to induce other characteristics to the bulk material, other than catalysis, encourages an integrated and sustainable approach to material development [1-3]. Integrated approaches include catalysis-adsorption, oxidation-catalysis, photocatalysis-degradation, photodegradation-adsorption, etc., achieved with the same functionalized material/composite [117, 120-122]. N-doped carbon-supported metal supports have shown higher catalytic efficiency

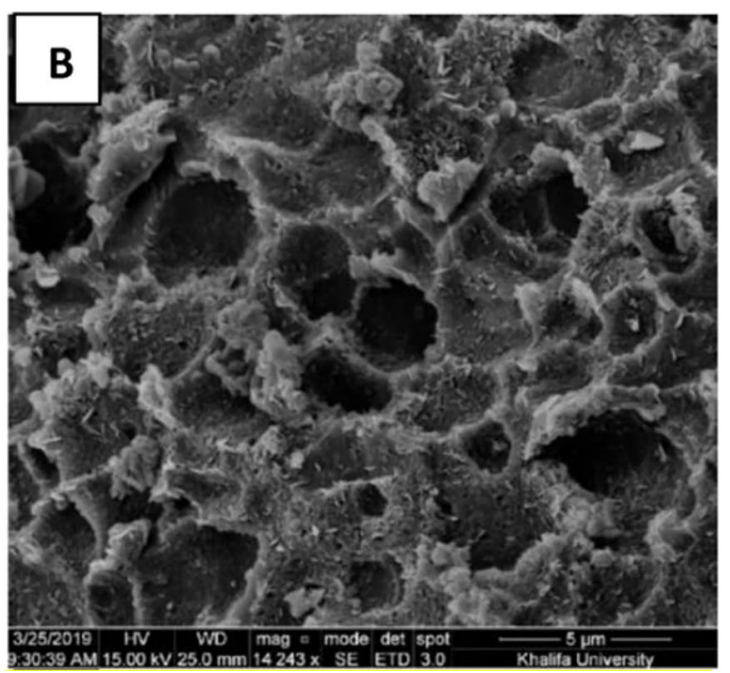

Fig. 7 Scanning electron microscopic image of carbon-based materials revealing pores suitable for loading of catalyst (adapted with slight modification from Khan et al. [127] copyright 2019 Nature Research)
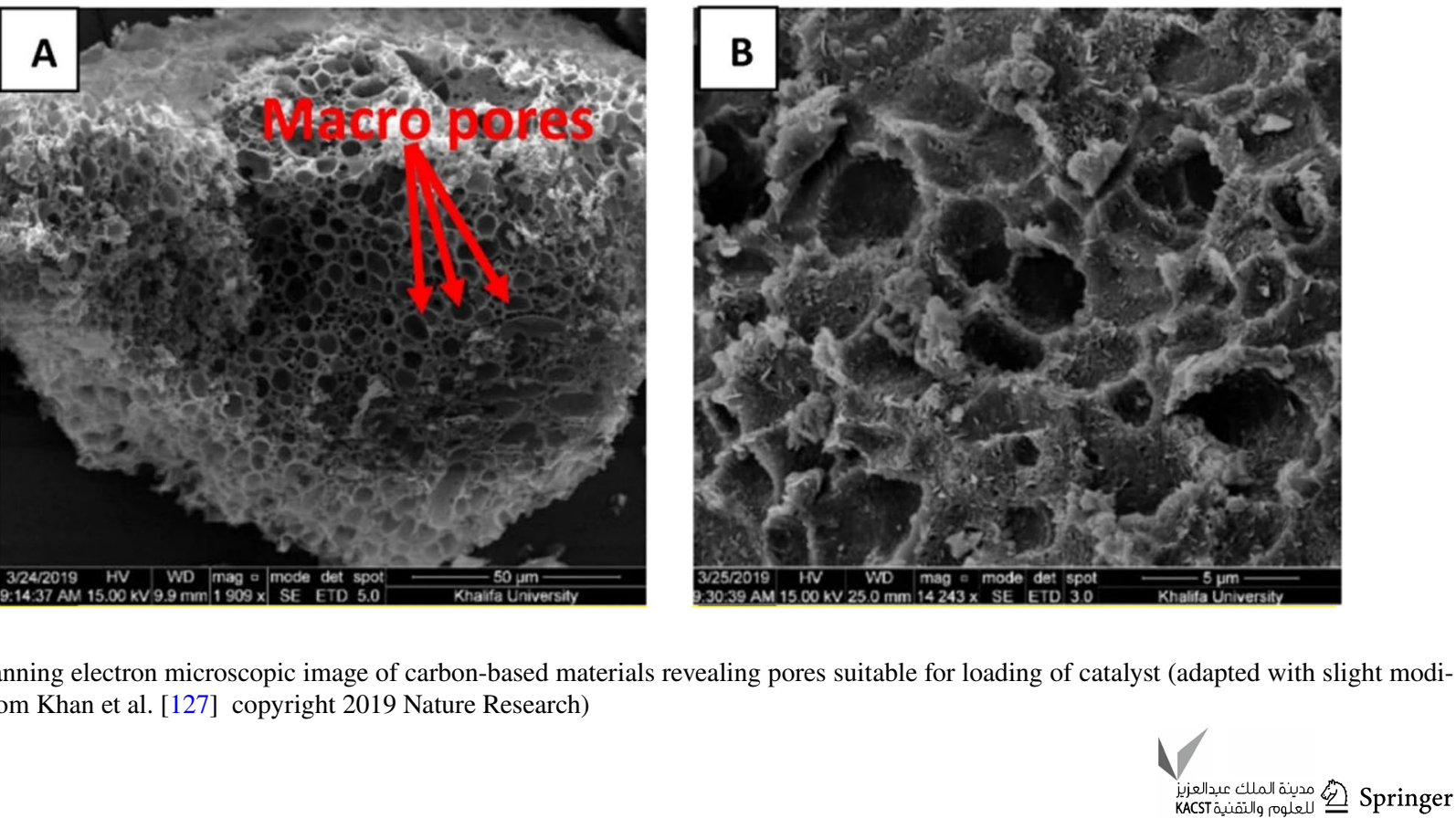
in several heterogeneous catalytic reactions, than the conventional, pristine carbon supports [3].

Metal-matrix composite (MMC) and metal-organic frameworks (MOF) have reported improvements in microand macro-structure and mechanical properties such as hardness, tensile strength, and density [84]. For catalysis and other applications, carefully controlled integration of MOFs and functional materials (e.g., metallic nanoparticles, quantum dots, enzymes, silica, and polymers), enhances the properties, activity, and stability of MOFs and MMCs. Metal-organic frameworks can cooperatively and sustainably minimize catalytic poisoning, and enhance the catalytic activity, selectivity, and stability in a variety of chemical processes [84-86]. Recent studies recommend the use of sustainable materials such as aluminium-magnesium-based matrix composites and agricultural waste-derived biochars as reinforcements in MMCs for industrial applications. Furthermore, stir casting is regarded as the most cost-effective, simple, and efficient technique for producing MMCs [2, 123].

There is a need to reduce the sulphur present in petroleum products to $\leq 1 \mathrm{ppm}$ if it is to be used as feedstock for producing hydrogen meant for fuel cell applications, because of the use of noble-metal catalysts in downstream processes, especially in the fuel cell. Additionally, the conversion of hydrocarbon fuel feeds to the fuel cell set up entails $0.1 \mathrm{ppm}$ sulphur reduction. The implication of this is that a daunting task is required to provide catalysts whose catalytic activities are seven times above the existing catalyst for achieving $500 \mathrm{ppm}$ of sulphur removal. Apart from the high activity, the catalysts should possess distinct activity profiles with respect to different functionalities. The variation of the support is a vital approach that has been attempted for the modification of the catalysts to achieve the above objectives [94, 124].

Diverse environmental regulations have focused on the reduction of the extent of environmental pollution through lowering the level of sulphur, nitrogen, and metals, particularly nickel and vanadium contents in commercial fuels. Owing to this, there is a need for the reduction of concentrations of contaminants like sulphur in fractions of petroleum, especially in gasoline and middle distillates [91]. It is presumed that the hydrotreating processes can occur via the isomerization of a methyl group or the hydrogenation of phenyl rings in sulphur-containing compounds with steric hindrance $[39,125,126]$. The proposed isomerization and hydrogenation processes can be enhanced by the introduction of mesoporous catalysts into support matrices. The hydrodesulphurization processes can also be enhanced by the use of chelating agents during the preparation of the catalyst.

\section{Conclusion}

The current industry practice is the predominant use of zeolite as a catalyst during catalytic cracking of crude oil. The selectivity of conventional catalysts for specific reactions during cracking has led to the impregnation of existing catalytic materials with metals to form composite materials. The metallic composites have become prominent catalysts not only for the catalytic cracking of crude oil but also in the catalytic cracking of palm oil and rubber seed oil, leading to the production of usable and reusable high-value products. The metallic composites rely basically on their various properties such as high thermal stability, attrition resistance, and high catalytic activity. Thus, they are the first-choice materials for numerous cracking processes occurring in the petrochemical industries and refineries. However, many challenges still exist in the development of composite catalysts with both mesoporous and microporous advantages. Simultaneously, not every combination of a matrix and reinforcement can be processed into useful composite catalysts except by interfacial modifications, and catalyst poisoning and deactivation are challenges requiring future research endeavour. Therefore, future research should be carried out on surface modification, stability improvement, ease of regeneration, and efficiency optimization of these composite catalysts.

\section{Compliance with ethical standards}

Conflict of interest The authors declare that there is no conflict of interest.

Open Access This article is licensed under a Creative Commons Attribution 4.0 International License, which permits use, sharing, adaptation, distribution and reproduction in any medium or format, as long as you give appropriate credit to the original author(s) and the source, provide a link to the Creative Commons licence, and indicate if changes were made. The images or other third party material in this article are included in the article's Creative Commons licence, unless indicated otherwise in a credit line to the material. If material is not included in the article's Creative Commons licence and your intended use is not permitted by statutory regulation or exceeds the permitted use, you will need to obtain permission directly from the copyright holder. To view a copy of this licence, visit http://creativecommons.org/licenses/by/4.0/.

\section{References}

1. Cao Y, Mao S, Li M, Chen Y, Wang Y (2017) Metal/porous carbon composites for heterogeneous catalysis: old catalysts with improved performance promoted by N-doping. ACS Catal 7:8090-8112

2. Mallesham B, Raikwar D, Shee D (2020) The role of catalysis in green synthesis of chemicals for sustainable future. In: Mustansar Hussain C, Sudarsanam P (eds) Advanced functional solid catalysts for biomass valorization. Elsevier, Amsterdam, pp 1-37 
3. Xu Y, Wang R, Liu Z, Gao L, Jiao T, Liu Z (2020) $\mathrm{Ni}_{2} \mathrm{P} / \mathrm{MoS}_{2}$ interfacial structures loading on $\mathrm{N}$-doped carbon matrix for highly efficient hydrogen evolution. Green Energy Environ. https ://doi.org/10.1016/j.gee.2020.12.008

4. Alfke G, Irion WW, Neuwirth OS (2007) Oil refining. Ullmann's Encycl Ind Chem. https://doi.org/10.1002/14356007.a18_051. pub2

5. Sadare OO, Obazu F, Daramola MO (2017) Biodesulfurization of petroleum distillates-current status. Oppor Future Chall Environ $4: 85$

6. Ratnasari DK, Nahil MA, Williams PT (2017) Catalytic pyrolysis of waste plastics using staged catalysis for production of gasoline range hydrocarbon oils. J Anal Appl Pyrol 124:631-637. https:// doi.org/10.1016/j.jaap.2016.12.027

7. Speight JG (2019) Catalytic cracking processes. Heavy oil recovery and upgrading. Gulf Professional Publishing, Houston

8. Yusuf M, Farooqi AS, Keong LK, Hellgardt K, Abdullah B (2020) Contemporary trends in composite Ni-based catalysts for $\mathrm{CO}_{2}$ reforming of methane. Chem Eng Sci 229:116072

9. Juneau M, Liu R, Peng Y, Malge A, Ma Z, Porosoff MD (2020) Characterization of metal-zeolite composite catalysts: determining the environment of the active phase. ChemCatChem. https:// doi.org/10.1002/cctc.201902039

10. Fodor D, Ishikawa T, Krumeich F, van Bokhoven JA (2015) Synthesis of single crystal nanoreactor materials with multiple catalytic functions by incipient wetness impregnation and ion exchange. Adv Mater 27(11):1919-1923

11. Li F, Du J, Li X, Shen J, Wang Y, Zhu Y, Sun L (2018) Integration of $\mathrm{FeOOH}$ and zeolitic imidazolate framework-derived nanoporous carbon as an efficient electrocatalyst for water oxidation. Adv Energy Mater 8(10):1702598

12. Wenderich K, Mul G (2016) Methods, mechanism, and applications of photodeposition in photocatalysis: a review. Chem Rev 116(23): 14587-14619

13. Yang CC, Yacob S, Kilos BA, Barton DG, Weitz E, Notestein JM (2016) Increased productivity in ethylene carbonylation by zeolite-supported molybdenum carbonyls. J Catal 338:313-320

14. Stojanović B, Ivanović L (2015) Application of aluminium hybrid composites in automotive industry. Tehnički vjesnik 22(1):247-251. https://doi.org/10.17559/TV-20130905094303

15. Trinh SN, Sastry S (2016) Processing and properties of metal matrix composites. Mechanical engineering and materials science independent study. Springer, New York, p 10

16. Kainer KU (2006) Basics of metal matrix composites. WileyVCH GmbH \& Co. KGaA, Weinheim

17. Chang WH, Tye CT (2013) Catalytic cracking of used palm oil using composite zeolite. Malays J Anal Sci 17(1):176-184

18. Emori EY, Hirashima FH, Zandonai $\mathrm{CH}$, Ortiz-Bravo CA, Fernandes-Machado NRC, Olsen-Scaliante MHN (2017) Catalytic cracking of soybean oil using ZSM5 zeolite. Catal Today 279:168-176

19. Sharma S, Saxena V, Baranwal A, Chandra P, Pandey LM (2018) Engineered nanoporous materials mediated heterogeneous catalysts and their implications in biodiesel production. Mater Sci Energy Technol 1:11-21

20. Oenema J, Harmel J, Vélez RP, Meijerink MJ, Eijsvogel W, Poursaeidesfahani A, Vlugt TJH, Zecevic J, de Jong KP (2020) Influence of nanoscale intimacy and zeolite micropore size on the performance of bifunctional catalysts for $n$-heptane hydroisomerization. ACS Catal 10:14245-14257

21. Sharma R, Jhap S, Kakkar K, Kamboj A, Sharma P (2017) A review of the aluminium metal matrix composite and its properties. Int Res J Eng Technol 4(02):679

22. Blay V, Louis B, Miravalles R, Yokoi T, Peccatiello KA, Clough M, Yilmaz B (2017) Engineering zeolites for catalytic cracking to light olefins. ACS Catal 7(10):6542-6566. https:// doi.org/10.1021/acscatal.7b02011

23. Sushkevich VL, Palagin D, Ranocchiari M, van Bokhoven JA (2017) Selective anaerobic oxidation of methane enables direct synthesis of methanol. Science 356(6337):523-527

24. Weitkamp J (2012) Catalytic hydrocracking - mechanisms and versatility of the process. ChemCatChem 4(3):292-306

25. Li Y, Amin MN, Lu X, Li C, Ren F, Zhang S (2016) Pyrolysis and catalytic upgrading of low-rank coal using a $\mathrm{NiO} / \mathrm{MgO}$ $\mathrm{Al}_{2} \mathrm{O}_{3}$ catalyst. Chem Eng Sci 155:194-200

26. Murugappan K, Mukarakate C, Budhi S, Shetty M, Nimlos MR, Román-Leshkov Y (2016) Supported molybdenum oxides as effective catalysts for the catalytic fast pyrolysis of lignocellulosic biomass. Green Chem 18(20):5548-5557

27. He L, Hui H, Li S, Lin W (2018) Production of light aromatic hydrocarbons by catalytic cracking of coal pyrolysis vapors over natural iron ores. Fuel 216:227-232

28. Mante OD, Dayton DC, Carpenter JR, Wang K, Peters JE (2018) Pilot-scale catalytic fast pyrolysis of loblolly pine over $\gamma-\mathrm{Al}_{2} \mathrm{O}_{3}$ catalyst. Fuel 214:569-579

29. Wang D, Wang D, Yu J, Chen Z, Li Y, Gao S (2019) Role of alkali sodium on the catalytic performance of red mud during coal pyrolysis. Fuel Process Technol 186:81-87

30. Taj R, Pervaiz E, Hussain A (2020) Synthesis and catalytic activity of IM-5 zeolite as naphtha cracking catalyst for light olefins: a review. J Chem Soc Pak 42(2):305-316

31. Javadli R, De Klerk A (2012) Desulfurization of heavy oil. Appl Petrochem Res 1(1-4):3-19. https://doi.org/10.1007/s1320 3-012-0006-6

32. Sikarwar VS, Zhao M, Fennell PS, Shah N, Anthony EJ (2017) Progress in biofuel production from gasification. Prog Energy Combust Sci 61:189-248

33. Degnan TF (2000) Applications of zeolites in petroleum refining. Top Catal 13(4):349-356

34. Dincer I, Rosen MA (2005) Thermodynamic aspects of renewables and sustainable development. Renew Sustain Energy Rev 9(2):169-189

35. Gholami Z, Luo G, Gholami F, Yang F (2020) Recent advances in selective catalytic reduction of $\mathrm{NO}_{x}$ by carbon monoxide for flue gas cleaning process: a review. Catal Rev. https://doi. org/10.1080/01614940.2020.1753972

36. Manisalidis I, Stavropoulou E, Stavropoulos A, Bezirtzoglou E (2020) Environmental and health impacts of air pollution: a review. Front Public Health. https://doi.org/10.3389/fpubh .2020 .00014

37. González-Cortés SL, Qian Y, Almegren HA, Xiao T, Kuznetsov VL, Edwards PP (2015) Citric acid-assisted synthesis of $\gamma$-alumina-supported high loading CoMo sulfide catalysts for the hydrodesulfurization (HDS) and hydrodenitrogenation (HDN) reactions. Appl Petrochem Res 5(3):181-197. https:// doi.org/10.1007/s13203-015-0097-y

38. Alves L, Paixão SM, Pacheco R, Ferreira AF, Silva CM (2015) Biodesulphurization of fossil fuels: energy, emissions and cost analysis. RSC Adv 5:34047-34057

39. Asadi AA, Royaee SJ, Alavi SM, Bazmi M (2019) Ultra-deep hydrodesulfurization of cracked and atmospheric gasoil blend: direct and interactive impacts of support composition, chelating agent, metal and promoter loadings. Fuel Process Technol 187:36-51

40. Yuan CS, Lin HY, Lee WJ, Lin YC, Wu TS, Chen KF (2007) A new alternative fuel for reduction of polycyclic aromatic hydrocarbon and particulate matter emissions from diesel engines. $\mathbf{J}$ Air Waste Manag Assoc 57:465-471

41. Elfghi FM, Amin NAS (2011) Parametric study of hydrodesulphurization and hydroaromatization of gasoil in hydrotreating

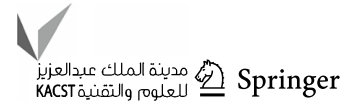


process over CoMo-S catalyst using pilot plant integral reactor. J Teknol 56(1):53-73

42. Tiwari R, Rana BS, Kumar R, Sinha KA (2012) $\mathrm{TiO}_{2}-\mathrm{ZrO}_{2}$ binary oxides for effective hydrodesulfurization catalysts. Open Catal J 5(1):39-49

43. Ling TR, Wan BZ, Lin HP, Mou CY (2009) Desulphurization of vacuum gasoil by MCM-41 supported molybdenum-nickel catalysts. Ind Eng Chem Res 48(4):1797-1803. https://doi. org/10.1021/ie8014389

44. Mouli KC, Soni K, Dalai A, Adjaye J (2011) Effect of pore diameter of Ni-Mo/Al-SBA-15 catalysts on the hydrotreating of heavy gas oil. Appl Catal A 404(1-2):21-29. https://doi.org/10.1016/j. apcata.2011.07.001

45. Solís-Casados DA, Escobar-Alarcón L, Klimova T, EscobarAguilar J, Rodríguez-Castellón E, Cecilia JA, Morales-Ramírez $\mathrm{C}$ (2016) Catalytic performance of $\mathrm{CoMo} / \mathrm{Al}_{2} \mathrm{O}_{3}-\mathrm{MgO}-\mathrm{Li}_{\mathrm{x}}$ formulations in DBT hydrodesulfurization. Catal Today 271:35-44. https://doi.org/10.1016/j.cattod.2015.07.046

46. Egorova M (2003) Study of aspects of deep hydrodesulfurization by means of model reactions. Doctoral dissertation, ETH Zurich

47. Corma A, Martınez C, Ketley G, Blair G (2001) On the mechanism of sulfur removal during catalytic cracking. Appl Catal A 208(1-2):135-152

48. Corma A, Sauvanaud L, Mathieu Y, Al-Bogami S, Bourane A, Al-Ghrami M (2018) Direct crude oil cracking for producing chemicals: thermal cracking modeling. Fuel 211:726-736. https ://doi.org/10.1016/j.fuel.2017.09.099

49. Dai YL, Zheng SQ, Qian D (2009) Sulphur reduction in fluid catalytic cracking using a kaolin in situ crystallization catalyst modified with vanadium. Clay Miner 44(3):281-288. https:// doi.org/10.1180/claymin.2009.044.3.281

50. Glotov A, Levshakov N, Vutolkina A, Lysenko S, Karakhanov E, Vinokurov V (2019) Aluminosilicates supported La-containing sulfur reduction additives for FCC catalyst: correlation between activity, support structure and acidity. Catal Today 329:135-141. https://doi.org/10.1016/j.cattod.2018.10.009

51. Li H, Li M, Chu Y, Liu F, Nie H (2014) Effect of different preparation methods of $\mathrm{MoO}_{3} / \mathrm{Al}_{2} \mathrm{O}_{3}$ catalysts on the existing states of Mo species and hydrodesulfurization activity. Fuel 116:168-174. https://doi.org/10.1016/j.fuel

52. Li P, Chen Y, Zhang C, Huang B, Liu X, Liu T, Jiang Z, Li C (2017) Highly selective hydrodesulfurization of gasoline on unsupported Co-Mo sulfide catalysts: effect of $\mathrm{MoS}_{2}$ morphology. Appl Catal A 533:99-108. https://doi.org/10.1016/j.apcat a.2017.01.009

53. Mendoza-Nieto JA, Vera-Vallejo O, Escobar-Alarcón L, SolísCasados D, Klimova T (2013) Development of new trimetallic NiMoW catalysts supported on SBA-15 for deep hydrodesulfurization. Fuel 110:268-277. https://doi.org/10.1016/j. fuel.2012.07.057

54. Liu B, Liu L, Chai Y, Zhao J, Li Y, Liu Y, Liu C (2018) Highly active $\mathrm{CoMoS} / \mathrm{Al}_{2} \mathrm{O}_{3}$ catalysts ex situ presulfided with ammonium sulfide for selective hydrodesulfurization of fluid catalytic cracking gasoline. Ind Eng Chem Res 57(6):2041-2049. https://doi.org/10.1021/acs.iecr.7b04929

55. Elgowainy A, Han J, Cai H, Wang M, Forman GS, DiVita VB (2014) Energy efficiency and greenhouse gas emission intensity of petroleum products at US refineries. Environ Sci Technol 48(13):7612-7624

56. Ren XY, Feng XB, Cao JP, Tang W, Wang ZH, Yang Z, Zhao JP, Zhang LY, Wang YJ, Zhao XY (2020) Catalytic conversion of coal and biomass volatiles: a review. Energy Fuels 34(9):10307-10363

57. Wang F, Wang G, Bing L, Wang Y, Tian A, Yi K (2017) Effect of preparation method on Ag modified Ti-HMS catalyst structure and catalytic oxidative desulphurization performance. Int J Chem React Eng. https://doi.org/10.1515/ijcre-2017-0112

58. Bose D (2015) Design parameters for a hydro desulfurization (HDS) unit for petroleum naphtha at 3500 barrels per day. World Sci News 9:99-111

59. Porgar S, Rahmanian N (2015) Hydrodesulfurization of crude oil over Co-Mo catalysts in a slurry reactor. J Multidiscip Eng Sci Technol 2:1205-1211

60. Demirbas A (2016) Sulfur removal from crude oil using supercritical water. Pet Sci Technol 34(7):622-626. https://doi. org/10.1080/10916466.2016.1154871

61. Siddiqui MB, Ahmed S, Aitani AM, Dean CF (2006) Sulfur reduction in FCC gasoline using catalyst additives. Appl Catal A 303(1):116-120. https://doi.org/10.1016/j.apcat a.2006.02.012

62. Tang L, Luo G, Kang L, Zhu M, Dai B (2013) A novel [Bmim] PW/HMS catalyst with high catalytic performance for the oxidative desulfurization process. Korean J Chem Eng 30(2):314-320. https://doi.org/10.1007/s11814-012-0182-1

63. Mendoza-Nieto JA, Robles-Méndez F, Klimova TE (2015) Support effect on the catalytic performance of trimetallic NiMoW catalysts prepared with citric acid in HDS of dibenzothiophenes. Catal Today 250:47-59. https://doi.org/10.1016/j.catto d.2014.05.002

64. Ahmedzeki NS, Al-Tabbakh BA, Antwan MB, Yilmaz S (2018) Heavy naphtha upgrading by catalytic reforming over novel bifunctional zeolite catalyst. React Kinet Mech Catal 125(2):11271138. https://doi.org/10.1007/s11144-018-1432-y

65. Semeykina VS, Parkhomchuk EV, Polukhin AV, Parunin PD, Lysikov AI, Ayupov AB, Cherepanova SV, Kaichev VV, Glazneva TS (2016) CoMoNi catalyst texture and surface properties in heavy oil processing. Part II: macroporous sepiolite-like mineral. Ind Eng Chem Res 55(34):9129-9139. https://doi. org/10.1021/acs.iecr.6b01208

66. Sundaramurthy V, Eswaramoorthi I, Dalai AK, Adjaye J (2008) Hydrotreating of gas oil on SBA-15 supported NiMo catalysts. Microporous Mesoporous Mater 111(1-3):560-568. https://doi. org/10.1016/j.micromeso.2007.08.037

67. Baldovino-Medrano VG, Giraldo SA, Centeno A (2008) The functionalities of $\mathrm{Pt} / \gamma-\mathrm{Al}_{2} \mathrm{O}_{3}$ catalysts in simultaneous HDS and HDA reactions. Fuel 87(10-11):1917-1926. https://doi. org/10.1016/j.fuel.2007.12.008

68. Villarreal A, Ramírez J, Caero LC, Villalón PC, Gutiérrez-Alejandre A (2015) Importance of the sulfidation step in the preparation of highly active $\mathrm{NiMo} / \mathrm{SiO}_{2} / \mathrm{Al}_{2} \mathrm{O}_{3}$ hydrodesulfurization catalysts. Catal Today 250:60-65. https://doi.org/10.1016/j.catto d.2014.03.035

69. Baldovino-Medrano VG, Eloy P, Gaigneaux EM, Giraldo SA, Centeno A (2010) Factors controlling the development of the HYD route of desulphurization of DBT over $\gamma$-alumina supported Pt and Pd catalysts. Catal Today 150(3-4):186-195. https ://doi.org/10.1016/j.cattod.2009.07.106

70. Yang L, Li X, Wang A, Prins R, Chen Y, Duan X (2015) Hydrodesulfurization of dibenzothiophene, 4,6-dimethyldibenzothiophene, and their hydrogenated intermediates over bulk tungsten phosphide. J Catal 330:330-343

71. Bains PS, Sidhu SS, Payal HS (2016) Fabrication and machining of metal matrix composites: a review. Mater Manuf Process 31(5):553-573

72. Kaczmar JW, Pietrzak K, Włosiński W (2000) The production and application of metal matrix composite materials. J Mater Process Technol 106(1-3):58-67. https://doi.org/10.1016/S0924 -0136(00)00639-7

73. Karami D, Mahinpey N (2016) Application of novel zeolite Y nanoparticles in catalytic cracking reactions. Chem Eng Commun 203(2):251-257. https://doi.org/10.1080/00986445.2014.993467 
74. Huq R (2009) Flexural strength of three types of glass powder reinforced vinyl ester composites.

75. Bai P, Etim UJ, Yan Z, Mintova S, Zhang Z, Zhong Z, Gao $X$ (2019) Fluid catalytic cracking technology: current status and recent discoveries on catalyst contamination. Catal Rev 61(3):333-405. https://doi.org/10.1080/01614940.2018.1549011

76. Carvalho A, Marinova M, Batalha N, Marcilio NR, Khodakov AY, Ordomsky VV (2017) Design of nanocomposites with cobalt encapsulated in the zeolite micropores for selective synthesis of isoparaffins in Fischer-Tropsch reaction. Catal Sci Technol 7(21):5019-5027

77. Peron DV, Zholobenko VL, de la Rocha MR, de Souza MO, Feris LA, Marcilio NR, Ordomsky VV, Khodakov AY (2019) Nickel-zeolite composite catalysts with metal nanoparticles selectively encapsulated in the zeolite micropores. J Mater Sci 54(7):5399-5411

78. Klimova T, Lizama L, Amezcua JC, Roquero P, Terrés E, Navarrete J, Domínguez JM (2004) New NiMo catalysts supported on Al-containing SBA-16 for 4,6-DMDBT hydrodesulfurization: effect of the alumination method. Catal Today 98(1-2):141-150. https://doi.org/10.1016/j.cattod.2004.07.028

79. Lam E, Luong JHT (2014) Carbon materials as catalyst supports and catalysts in the transformation of biomass to fuels and chemicals. ACS Catal 4:3393-3410

80. van Deelen TW, Hernández Mejía C, de Jong KP (2019) Control of metal-support interactions in heterogeneous catalysts to enhance activity and selectivity. Nat Catal 2:955-970. https:// doi.org/10.1038/s41929-019-0364-x

81. Nemati Kharat A, Zafari R (2013) Application of zeolitic additives in the fluid catalytic cracking (FCC). J Nanostruct 3(2):209-217

82. Vogt ETC, Weckhuysen BM (2015) Fluid catalytic cracking: recent developments on the grand old lady of zeolite catalysis. Chem Soc Rev 44:7342-7370

83. Perego C, Millini R (2013) Porous materials in catalysis: challenges for mesoporous materials. Chem Soc Rev 42(9):39563976. https://doi.org/10.1039/c2cs35244c

84. Maina JW, Pozo-Gonzalo C, Kong L, Schütz J, Hill M, Dumée LF (2017) Metal organic framework based catalysts for $\mathrm{CO}_{2}$ conversion. Mater Horiz 4:345-361

85. Sievers C, Noda Y, Qi L, Albuquerque EM, Rioux RM, Scott SL (2016) Phenomena affecting catalytic reactions at solidliquid interfaces. ACS Catal 6:8286-8307

86. Chen L, Xu Q (2019) Metal-organic framework composites for catalysis. Matter 1:57-89

87. Charisiou ND, Siakavelas G, Tzounis L, Dou B, Sebastian V, Hinder SJ, Baker MA, Polychronopoulou K, Goula MA (2019) $\mathrm{Ni} / \mathrm{Y}_{2} \mathrm{O}_{3}-\mathrm{ZrO}_{2}$ catalyst for hydrogen production through the glycerol steam reforming reaction. Int J Hydrog Energy. https ://doi.org/10.1016/j.ijhydene.2019.04.237

88. Padmakar D, Surendar M, Chandrashekar P, Lingaiah N (2020) Highly stable and efficient $\mathrm{Co}-\mathrm{Mg}-\mathrm{Sr}$ mixed oxide catalysts for hydrogen production from glycerol steam reforming. Catal Lett. https://doi.org/10.1007/s10562-020-03181-4

89. Kim H-M, Jang W-J, Yoo S-Y, Shim J-O, Jeon K-W, Na H-S, Lee Y-L, Jeon B-H, Bae JW, Roh H-S (2018) Low temperature steam reforming of methane using metal oxide promoted $\mathrm{Ni}-\mathrm{Ce} 0.8 \mathrm{Zr} 0.2 \mathrm{O}_{2}$ catalysts in a compact reformer. Int $\mathrm{J}$ Hydrog Energy 43(1):262-270. https://doi.org/10.1016/j.ijhyd ene.2017.11.058

90. Stanislaus A, Marafi A, Rana MS (2010) Recent advances in the science and technology of ultra low sulfur diesel (ULSD) production. Catal Today 153(1-2):1-68

91. Trejo F, Rana MS, Ancheyta J (2008) CoMo/MgO- $\mathrm{Al}_{2} \mathrm{O}_{3}$ supported catalysts: an alternative approach to prepare
HDS catalysts. Catal Today 130(2-4):327-336. https://doi. org/10.1016/j.cattod.2007.10.105

92. Wagenhofer MF, Shi H, Gutiérrez OY, Jentys A, Lercher JA (2020) Enhancing hydrogenation activity of Ni-Mo sulfide hydrodesulfurization catalysts. Sci Adv 6:eaax5331

93. Yin A, Guo X, Dai WL, Fan K (2009) The nature of active copper species in $\mathrm{Cu}$-HMS catalyst for hydrogenation of dimethyl oxalate to ethylene glycol: new insights on the synergetic effect between $\mathrm{Cu} 0$ and $\mathrm{Cu}^{+}$. J Phys Chem C 113(25):11003-11013. https://doi.org/10.1021/jp902688b

94. Kumaran GM, Garg S, Soni K, Kumar M, Sharma LD, Dhar GM, Rao KR (2006) Effect of Al-SBA-15 support on catalytic functionalities of hydrotreating catalysts: I. Effect of variation of Si/Al ratio on catalytic functionalities. Appl Catal A Gen 305(2):123-129. https://doi.org/10.1016/j.apcata.2006.02.057

95. Jin MH, Oh D, Park JH (2016) Mesoporous silica supported $\mathrm{Pd}-\mathrm{MnO}_{x}$ catalysts with excellent catalytic activity in roomtemperature formic acid decomposition. Sci Rep 6:33502. https ://doi.org/10.1038/srep33502

96. Chen J, Zhou J, Wang R, Zhang J (2009) Preparation, characterization, and performance of HMS-supported Ni catalysts for hydrodechlorination of chorobenzene. Ind Eng Chem Res 48(8):3802-3811. https://doi.org/10.1021/ie801792h

97. Narayan R, Nayak UY, Raichur AM, Garg S (2018) Mesoporous silica nanoparticles: a comprehensive review on synthesis and recent advances. Pharmaceutics 10(3):118. https ://doi.org/10.3390/pharmaceutics10030118

98. Al-Shehri BM, Khder AERS, Ashour SS, Hamdy MS (2019) A review: the utilization of mesoporous materials in wastewater treatment. Mater Res Express 6:122002

99. Kumaran GM, Garg S, Soni K, Kumar M, Sharma LD, Rama Rao KS, Dhar GM (2007) Effect of Al-SBA-15 support on catalytic functionalities of hydrotreating catalysts. II. Effect of variation of molybdenum and promoter contents on catalytic functionalities. Ind Eng Chem Res 46(14):4747-4754. https://doi.org/10.1021/ ie060846x

100. Alsolami B, Carneiro JT, Moulijn JA, Makkee M (2011) On-site low-pressure diesel HDS for fuel cell applications: deepening the sulfur content to $\leq 1 \mathrm{ppm}$. Fuel 90(10):3021-3027. https://doi. org/10.1016/j.fuel.2011.05.024

101. Herrera JM, Reyes J, Roquero P, Klimova T (2005) New hydrotreating NiMo catalysts supported on MCM-41 modified with phosphorus. Microporous Mesoporous Mater 83(1-3):283-291. https://doi.org/10.1016/j.micromeso.2005.05.010

102. Silva-Rodrigo R, Hernández-López F, Martinez-Juarez K, Castillo-Mares A, Melo Banda JA, Olivas-Sarabia A, Ancheyta J, Rana MS (2008) Synthesis, characterization and catalytic properties of NiMo/ $\mathrm{Al}_{2} \mathrm{O}_{3}-\mathrm{MCM}-41$ catalyst for dibenzothiophene hydrodesulfurization. Catal Today 130:309-319

103. Nguyen HK, Dinh NT, Hoang DA (2010) Biodiesel production from rubber seed oil on heterogenous catalyst $\mathrm{Na}_{2} \mathrm{SiO}_{3} / \mathrm{SiO}_{2}$. In: Proceedings of the 5th international conference on innovations in food and bioprocess technology, vol 7, p 9

104. Morshed M, Ferdous K, Khan MR, Mazumder MSI, Islam MA, Uddin MT (2011) Rubber seed oil as a potential source for biodiesel production in Bangladesh. Fuel 90:2981-2986

105. Fumoto E, Sato S, Takanohashi T (2015) Desulphurization of heavy oil with iron oxide-based catalysts using steam. J Jpn Pet Inst 58(5):336-340. https://doi.org/10.1627/jpi.58.336

106. Fumoto E, Matsumura A, Sato S, Takanohashi T (2009) Recovery of lighter fuels by cracking heavy oil with zirconia-alumina-iron oxide catalysts in a steam atmosphere. Energy Fuels 23(3):1338-1341. https://doi.org/10.1021/ef8006257

107. Hajimirzaee S, Ainte M, Soltani B, Behbahani RM, Leeke GA, Wood J (2015) Dehydration of methanol to light olefins upon zeolite/alumina catalysts: effect of reaction conditions, catalyst

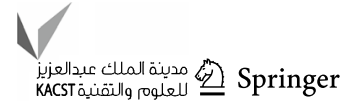


support and zeolite modification. Chem Eng Res Des 93:541553. https://doi.org/10.1016/j.cherd.2014.05.011

108. Gorzin F, Darian JT, Yaripour F, Mousavi SM (2019) Novel hierarchical HZSM-5 zeolites prepared by combining desilication and steaming modification for converting methanol to propylene process. J Porous Mater 26(5):1407-1425. https://doi. org/10.1007/s10934-019-00740-y

109. Xiao FS (2005) Ordered mesoporous materials with improved stability and catalytic activity. Top Catal 35:9-24. https://doi. org/10.1007/s11244-005-3809-1

110. Andrienko O, Kobotaeva N, Skorokhodova T, Marakina E, Sachkov V (2019) A removal of sulphur-containing compounds from fuel oils using a naturally occurring iron oxyhydroxide. AIP Conf Proc 2101(1):020009. https://doi.org/10.1063/1.5099601

111. Duarte FA, Mello PD, Bizzi CA, Nunes MA, Moreira EM, Alencar MS, Motta HN, Dressler VL, Flores ÉM (2011) Sulfur removal from hydrotreated petroleum fractions using ultrasoundassisted oxidative desulfurization process. Fuel 90:2158-2164

112. Qureshi MS, Nisar S, Shah R, Salman H (2020) Studies of liquid fuel formation from plastic waste by catalytic cracking over modified natural clay and nickel nanoparticles. Pak J Sci Ind Res Ser A Phys Sci 63(2):79-88

113. Munir D, Amer H, Aslam R, Bououdina M, Usman MR (2020) Composite zeolite beta catalysts for catalytic hydrocracking of plastic waste to liquid fuels. Mater Renew Sustain Energy 9:1-13

114. Wang L, Chen T, Zhang J, Jiao Y, Wang J, Zhu Q, Li X (2020) High catalytic activity and stability quasi homogeneous alkali metal promoted $\mathrm{Ni} / \mathrm{SiO}_{2}$ aerogel catalysts for catalytic cracking of $n$-decane. Fuel 268:117384

115. Yang Z, Ju X, Ma Z, Zhao J, Meng Z, Chen Z (2020) Preparation of composite catalyst and its catalytic cracking properties of coal tar. IOP Conf Ser Mater Sci Eng 729(1):012085

116. Wu C-H, Chang-Chien G-P, Lee W-S (2004) Photodegradation of polychlorinated dibenzo- $p$-dioxins: comparison of photocatalysts. J Hazard Mater 114:191-197

117. Kuznetsov DA, Han B, Yu Y, Rao RR, Hwang J, Román-Leshkov Y, Shao-Horn Y (2018) Tuning redox transitions via inductive effect in metal oxides and complexes, and implications in oxygen electrocatalysis. Joule 2:225-244

118. Garg A, Singhania T, Singh A, Sharma S, Rani S, Neogy A, Yadav SR, Sangal VK, Garg N (2019) Photocatalytic degradation of Bisphenol-A using N, Co codoped $\mathrm{TiO}_{2}$ catalyst under solar light. Sci Rep 9:765

119. Heidarzadeh A, Mohammadzadeh R, Brabazon D (2021) Green materials and production of metallic composite materials. JOM 45(1):1924. https://doi.org/10.1016/B978-0-12-80358 1-8.11912-5

120. Adeola AO, Fapohunda O, Jimoh AT, Toluwaloju TI, Ige AO, Ogunyele AC (2019) Scientific application and prospect of nanomaterials: a multidisciplinary review. Afr J Biotechnol 18:946-961

121. Adeola AO, Forbes PBC (2020) Advances in water treatment technologies for removal of polycyclic aromatic hydrocarbons: existing concepts, emerging trends, and future prospects. Water Environ Res. https://doi.org/10.1002/wer. 1420

122. Ore OT, Adeola AO (2020) Toxic metals in oil sands: review of human health implications, environmental impact, and potential remediation using membrane-based approach. Energy Ecol Environ. https://doi.org/10.1007/s40974-020-00196-w

123. Ononiwu NH, Akinlabi ET, Ozoegwu CG (2019) Sustainability in production and selection of reinforcement particles in aluminium alloy metal matrix composites: a review. J Phys Conf Ser 1378(4):042015

124. Védrine JC (2017) Heterogeneous catalysis on metal oxides. Catalysts 7:341

125. Badoga S, Dalai AK, Adjaye J, Hu Y (2017) Insights into individual and combined effects of phosphorus and EDTA on performance of $\mathrm{NiMo} / \mathrm{MesoAl}_{2} \mathrm{O}_{3}$ catalyst for hydrotreating of heavy gas oil. Fuel Process Technol 159:232-246

126. Pimerzin A, Mozhaev A, Varakin A, Maslakov K, Nikulshin P (2017) Comparison of citric acid and glycol effects on the state of active phase species and catalytic properties of $\mathrm{CoPMo} / \mathrm{Al}_{2} \mathrm{O}_{3}$ hydrotreating catalysts. Appl Catal B 205:93-103

127. Khan S, Achazhiyath Edathil A, Banat F (2019) Sustainable synthesis of graphene-based adsorbent using date syrup. Sci Rep 9:18106

Publisher's Note Springer Nature remains neutral with regard to jurisdictional claims in published maps and institutional affiliations 